Purdue University

Purdue e-Pubs

Purdue CIBER Working Papers

Krannert Graduate School of Management

$1-1-1999$

\title{
The Cadbury Committee, Corporate Performance and Top Management Turnover
}

Jay Dahya

Cardiff University

John J. McConnell

Purdue University

Nicolaos G. Travlos

Athens Laboratory of Business Administration and Cardiff University

Follow this and additional works at: http:// docs.lib.purdue.edu/ciberwp

Dahya, Jay; McConnell, John J.; and Travlos, Nicolaos G., "The Cadbury Committee, Corporate Performance and Top Management Turnover" (1999). Purdue CIBER Working Papers. Paper 140.

http://docs.lib.purdue.edu/ciberwp/140

This document has been made available through Purdue e-Pubs, a service of the Purdue University Libraries. Please contact epubs@purdue.edu for additional information. 
Center for International

Business Education and Research

\section{The Cadbury Committee, Corporate Performance and Top Management Turnover}

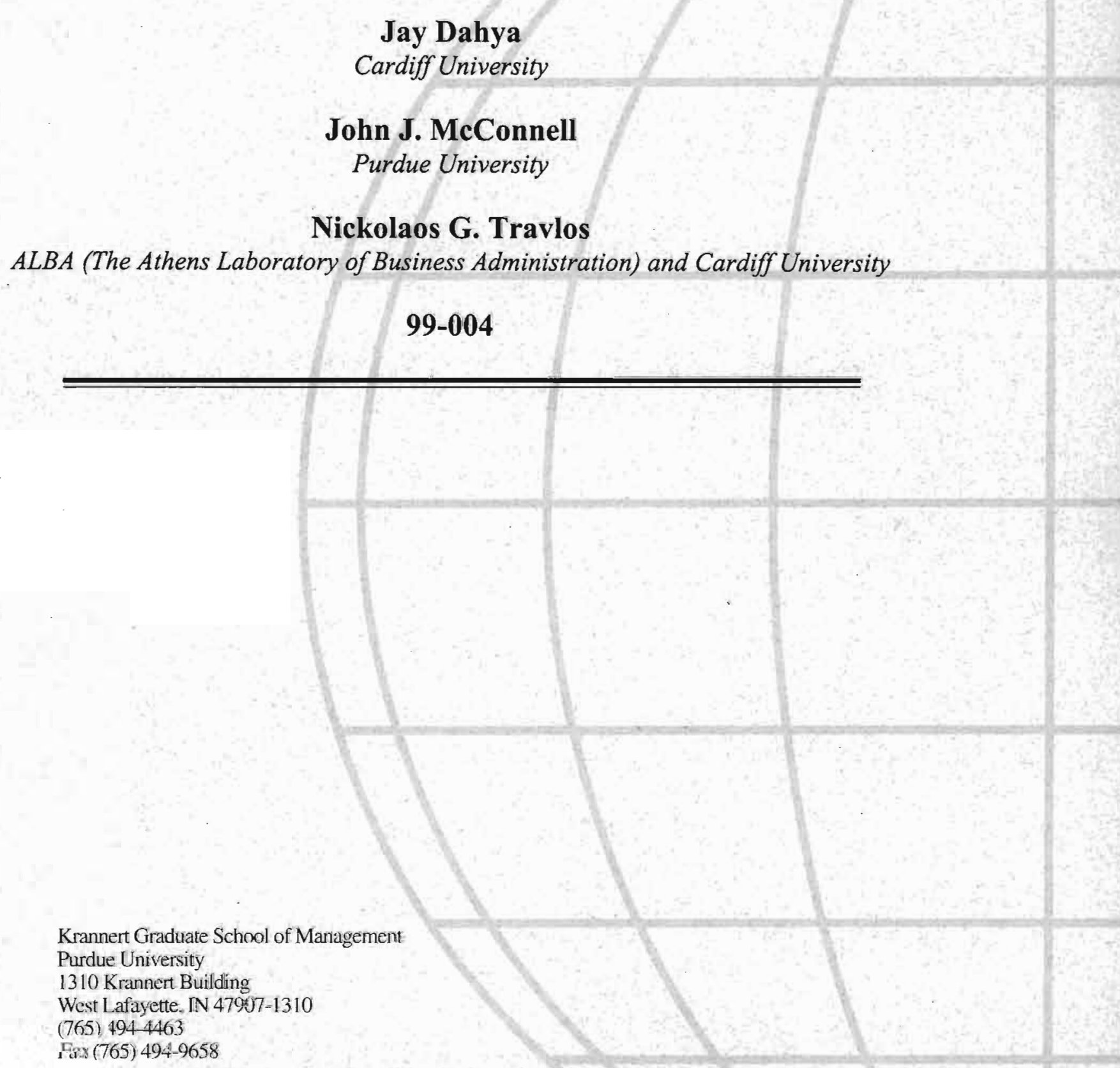

Krannert Graduate School of Management

Une University

West Lafayette, IN 47907-1310

Fax (765) 494-9658 


\title{
The Cadbury Committee, Corporate Performance and Top Management Turnover
}

\author{
Jay Dahya $^{a}$ \\ Cardiff University \\ John J. McConnell \\ Purdue University \\ and \\ Nickolaos G. Travlos \\ ALBA (The Athens Laboratory of Business Administration) and Cardiff University
}

January 13,2000

${ }^{a}$ Corresponding author. Cardiff Business School, Cardiff University, Aberconway Building, Colum Drive, Cardiff, CF1-3EU, United Kingdom. (Dahya@cf.ac.uk).

JEL Classification: G3; Keywords: Board Structure, Corporate Performance, Management Turnover

\section{Acknowledgement}

This paper has benefited from the helpful comments and suggestions of David Denis, Diane Denis, Robert Parrino, Ronan Powell, Raghu Rau, Andrew Stark and seminar participants at Purdue University, the EFMA (Paris) and the FMA (Orlando). McConnell acknowledges financial support from the Center for International Business Education and Research (CIBER) at Purdue University. Dahya acknowledges financial support received from the Leverhulme Trust. 


\section{The Cadbury Committee, Corporate Performance and Top Management Turnover}

In December 1992, the Cadbury Committee published the Code of Best Practice which recommended that boards of publicly-traded UK corporations include at least three outside directors and that the positions of the chairman of the board and chief executive officer not be held by a single individual. The underlying presumption was that these government-sponsored recommendations would lead to enhanced board oversight. As a test of that presumption, we analyze the relation between top management turnover and corporate performance. We find that CEO turnover increased following publications of the Code, that the relationship between CEO turnover and performance was strengthened following publication of the Code, and that the increase in the sensitivity of turnover to performance was concentrated among firms that adopted the Cadbury Committee's recommendations. 


\section{The Cadbury Committee, Corporate Performance and Top Management Turnover}

The Cadbury Committee was appointed by the Conservative Government of the United Kingdom (UK) in May 1991 with a broad mandate to “....address the financial aspects of corporate governance." In December 1992, the Committee issued its report which recommended, among other things, that boards of directors of publicly traded companies include at least three non-executive (i.e., outside) directors as members and that the positions of Chairman of the Board (Chairman) and Chief Executive Officer (CEO) of these companies be held by two different individuals. The apparent reasoning underlying the Committee's recommendations is that greater independence of a corporate board will improve the quality of board oversight.

To appreciate the potential significance of the Cadbury Committee and its recommendations, it is important to appreciate the environment surrounding the establishment of the Committee. First, the Committee was appointed in the aftermath of the "scandalous" collapse of several prominent UK companies during the later 1980s and early 1990s, including Ferranti International PLC, Colorol Group, Pollypeck International PLC, Bank of Credit and Commerce International (BCCI) and Maxwell Communication Corporation. The broadsheet press popularly attributed these failures and others to weak governance systems, lax board oversight, and the vesting of control in the hands of a single top executive.

The Cadbury Committee was set up in response to a number of corporate scandals that cast doubt on the systems for controlling the ways companies are

\footnotetext{
' Report of the Committee on the Financial Aspects of Corporate Governance (Section 1.8), December 1, 1992.
} 
run. The downfall of powerful figures such as Asil Nadir or the late Robert Maxwell, whose personal control over their companies was complete, raised fears about the concentration of power.

Self-regulation Seen as the Way Forward, Financial Times, May 28, 1992.

Second, historically, executive (i.e., inside) directors have heavily dominated UK boards. For example, during 1988, of the Financial Times 500, for only 21 companies did non-executive directors comprise a majority of the board and, when boards are ranked according to the fraction of non-executive board members, for the median board, nonexecutives comprised only 27 per cent of their membership. In comparison, during 1988, for 387 of the Fortune 500 U. S. companies, outsiders comprised a majority of the board. Furthermore, for the Fortune 500 companies, for the median board, outsiders comprised 81 per cent of the membership. With respect to the joint position of Chairman and CEO, the UK and US historically are not dissimilar. For example, during 1988, for 349 of the Fortune 500 companies and for 328 of the FTSE 500 companies, a single individual jointly held the positions of Chairman and CEO.

At its issuance, the Cadbury Report was greeted with skepticism both by those who felt that it went too far and by those who felt that it did not go far enough. The general unease of those who felt it went too far can best be summarized as a concern that the delicate balance between shareholders and managers is best left to the forces of competition. A less generous interpretation of this perspective, which was most frequently espoused by corporate managers, was "leave us alone - we know best".

There is danger in an over emphasis on monitoring, on non-executive directors independence from the business of the corporation; on controls over decision making activities of companies. When coupled with the clearly reduced status of executives on the governing boards, such requirements must blunt the 
competitive edge and deflect the entrepreneurial drive which characterises participants, let alone success in a free market.

Sir Owen Green, Pall Mall Lecture on UK Corporate Governance, February 24, 1994

The general concern of those who thought that the report did not go far enough centered on the "voluntary" nature of the Report's recommendations.

The committees' recommendations are steps in the right direction. But, if the government is to address the problems which led to the Maxwell, Polly Peck, $B C C I$ and other recent scandals, then new rules in a legal framework are required...Shareholders, investors and creditors will have been disappointed that just when the corporate failures of recent years cried out for bold and imaginative legal return, the body from which so much had been expected came up with a little, tinkering and a voluntary code.

Cadbury Committee Draft Orders Mixed News for Shareholders, Financial Times, June 2, 1992

The purpose of this study is to cast light on what heretofore has been largely a vitriolic dispute by investigating empirically the impact of the key Cadbury Committee recommendations - - that boards include at least three non-executive members and that the positions of Chairman and CEO be held by two different individuals - - on the quality of board oversight in UK firms over the period 1989 to 1995 . We begin our investigation with the presumption that an important oversight role of boards of directors is the hiring and firing of top corporate management. We further presume that one indicator of effective board oversight is that the board will replace poorly performing top management. With those presumptions in place, we empirically investigate the relationship between top management turnover and corporate performance before and after the Cadbury Committee issued its recommendations.

To conduct this investigation, we assemble a random sample of 460 UK companies from the Official List of the London Stock Exchange (LSE) as of December 1988. For each 
company, we collect information on top management turnover, board composition, and corporate performance for up to seven years before and four years after the issuance of the Cadbury Report. With these data, we determine that the relationship between top management turnover and corporate performance was statistically significant both before and after adoption of the Cadbury Committee's recommendations - - poorer performance is associated with higher turnover. Importantly, for our purposes, this relationship is significantly stronger following adoption of the Cadbury Committee's recommendations. Upon further exploration, the increased sensitivity of turnover to performance appears to be attributable to the increase in outside board members following Cadbury.

We view this study as making contributions in both the small and the large of corporate governance. From a narrow perspective, this study thoroughly examines the effect of the Cadbury Committee's recommendations on the relationship between top management turnover and corporate performance in the UK. From a broader perspective, this study contains implications for corporate governance and board composition generally, and augments studies by Agrawal and Knoeber (1994), Bhagat and Black (1996; 1998), Byrd and Hickman (1992), Cotter, Shivdasani and Zenner (1997), Denis and Sarin (1999), Hermalin and Weisbach (1998), Kaplan and Reishaus (1990), Kini, Kracaw and Mian (1995), Klein (1997), Kole and Lehn (1996), Rosenstein and Wyatt (1990), Shivdasani (1993), Weisbach (1988), Yermack (1996) and You, Caves, Smith and Henry (1986) among others. Our investigation also complements prior investigations of the relationship between top management turnover and corporate performance by Coughlan and Schmidt (1985), Denis and Denis (1995), Franks and Mayer (1997), Huson Parrino and Starks (1998), Jensen and Murphy (1990), Kang and Shivdasani (1995), Kaplan (1994a, b), Martin and McConnell 
(1991), Mikkelson and Partch (1997), Warner, Watts and Wruck (1988) and Weisbach (1988) among others.

The next section briefly describes the Cadbury Committee Report on the "Financial Aspects of Corporate Governance". Section II describes our sample selection procedure. Section III presents descriptive statistics for the sample. We reserve our review of related studies until after we present our empirical findings. In Section IV, we discuss our results in the context of prior empirical investigations and present our conclusions.

\section{Cadbury Committee Report}

The Cadbury Committee was chaired by a leading industrialist, Sir Adrian Cadbury, CEO of the Cadbury confectionery empire, and included other senior industry executives, finance specialists, and academics. The Committee was charged with examining the "financial aspects of corporate governance" in UK firms. The committee issued a draft report of its recommendations for public comment on May 27, 1992. Between then and December 1, 1992, the committee accepted comments and issued its final report on December 1, 1992.

The cornerstone of the Cadbury Report is "The Code of Best Practice" which presents the committee's recommendations on the structure and responsibilities of corporate boards of directors. The two key recommendations affecting the board structure were that boards of directors of publicly-traded companies include at least three outside directors as members and that the positions of Chairman and CEO be held by two different individuals. ${ }^{2}$

\footnotetext{
${ }^{2}$ The report also recommended: (i) full disclosure of the pay of the chairman and the highest paid director; (ii) shareholders' approval on executive directors contracts exceeding three years; (iii) executive directors pay be set by a board sub-committee (the remuneration committee) comprised primarily of outsiders and; (iv) directors should establish a sub-committee of the main board, comprised mainly of outside directors, to report on the effectiveness of the company's system of internal control, including mechanisms for risk assessment and management.
} 
As part of its report, the Committee "urged" that the boards of all companies registered on the Official List of the London Stock Exchange (LSE) comply with the Code and further "encouraged" that all other UK companies also aim to meet its guidelines. ${ }^{3}$ As such, compliance with "The Code of Best Practice" is entirely voluntary. That is, the Code has not been enshrined in UK corporate law. This does not imply, however, that the Code is "without teeth". First, the Cadbury Committee, as part of its report, explicitly recognized that legislation would very likely follow if companies did not comply with the guidelines of the Code. ${ }^{4}$ Second, the report has been given further bite by the LSE which, since June 1993, has required a statement from each listed company which spells out whether the firm is in compliance with the Code and, if not, further requires that an explanation be given as to why the company is not in compliance. As it turns out, this informal arm-twisting appears to have been effective: by 1998 all companies in the Financial Times 100 and over $90 \%$ of all firms on the Official List of the LSE were in compliance with the key provisions of the Code. The question that we investigate herein is whether adoption of the key provisions of the Cadbury Committee's recommendations has had a significant impact on the relationship between corporate performance and top management turnover.

\section{Sample Selection}

Our empirical investigation focuses on top management turnover during the eight-year interval surrounding the publication of the Cadbury Report in May 1992 (i.e., April 1988 through May 1996). Our analysis employs data on top management turnover and composition

\footnotetext{
${ }^{3}$ Report of the Committee on the Financial Aspects of Corporate Governance (Section 3.1), December 1, 1992.

${ }^{4}$ Report of the Committee on the Financial Aspects of Corporate Governance (Section 1.1), December 1, 1992.
} 
of boards of directors along with various measures of corporate performance for a random sample of publicly-traded UK firms. Additionally, our analysis employs certain financial data for these firms along with descriptive data for their boards and top management.

To begin construction of our sample, we randomly selected 650 industrial firms out of a total of 1,828 industrial firms contained in the Official List of the LSE as of year-end 1988 . For each of the 650 firms for which data are available in the Corporate Register for 1988, we determined the names of board members, the number of outside directors, the age of the top executive, the aggregate number of common shares held by the board, the number of shares held by institutional investors, and the number of block shareholders, where a block shareholder is defined as any shareholder owning greater than 3 per cent of the company's common stock. Such data are available for 548 of the firms in the initial sample. ${ }^{5}$ Stock price data and accounting data including the book value of total assets, total sales, the book value of liabilities, and earnings before depreciation, interest and taxes (EBDIT) are taken from Datastream for the years 1985 to 1988 . If such data are not available for the three years 1985 through 1988, the firm is dropped from the sample. Forty-seven of the 548 firms were dropped because of insufficient stock price data; an additional 41 firms were dropped due to insufficient accounting data. The resulting sample contains 460 firms. These firms were then identified according to their Financial Times (FT) industry classification. (The FT industry classification is roughly comparable to SIC classifications in the US.) The sample includes firms from 33 different industrial categories.

\footnotetext{
${ }^{5}$ Because of some apparent inconsistencies in share ownership data, we cross-checked these data with corporate annual reports at Companies House, Cardiff, Wales.
} 
To capture the characteristics of firms naturally leaving and entering the LSE population, when a firm in our sample ceases to be listed, we search chronologically among newly-listed industrial firms until we identify the first firm with book value of assets within $+/-20 \%$ of the book value of assets of the firm that ceased to be listed. For this firm to be eligible to enter our sample, we further require that data be available on management identity, board composition, share ownership, and financial performance. Finally, we require that if the existing firm was (was not) in compliance with the Code, the replacement firm must (must not) be in compliance. By following this procedure, a replacement firm was identified for each firm that ceased to be listed within at most four months following the delisting of that firm. We continue this procedure each year from 1988 onward, replacing firms that are no longer listed on the LSE, through the end of 1996 , so that the sample always contains 460 firms each year through the end of 1996.

For firms that continue in the sample, for each year, we collected the names of board members, the number of outside directors, the age of the top executive, the aggregate number of common shares held by the board, the number of shares held by institutional investors, and the number of block shareholders from the Corporate Register and take stock returns and accounting data from Datastream. When a new firm enters the sample, we gather financial data from its year of entry onward from Datastream and descriptive data for the board and management from the Corporate Register. Accounting data for three years prior to the LSE listing year are taken from filings with the LSE at the time of listing. The shares of some newly-listed firms had traded elsewhere prior to entering the LSE Official List. For these firms, stock price data are collected for up to three years preceding their listing date. For 
other firms, for which no prior stock price data are available, we use stock price data beginning with their entry date onto the Official List.

To determine top management turnover, we compare the names of top management from year to year over the time period 1986 through 1996. For each company, we identify the top executive as the individual with the title of CEO or Executive Chairman. ${ }^{6}$ In addition, we identify other board members as members of the top management team if the board member is an employee of the firm and holds the title of chief of operations or managing director. If the name of the top executive changes between successive years, we classify that as turnover in the top executive position. For other members of the top management team, if their name disappears from the top management list, that event is deemed to be a turnover in the top management team excluding the top executive. If the top executive leaves the list of top management and is replaced by another member of the top team, that event is considered turnover in the top executive position, but not turnover in the top management team (because that individual is still with the firm). We do not count as turnover, the event in which the position of Executive Chairman is split into the positions of Chairman of the board and CEO.

We classify turnover as "normal" or "forced" by examining news articles contained in the Extel Weekly News Summaries, the Financial Times, and Macarthy's News Information Service. A turnover event is considered to be forced under any of the following three circumstances: (1) a news article states that the executive was "fired"; (2) a news article states that the executive "resigned", the executive was less than 60 years old, no other article indicates that the executive had taken a position elsewhere, and no other article cites health,

${ }^{6}$ In those firms in which a single individual holds the positions of Chairman and CEO; that individual carries the title of Executive Chairman. 
family or death as the reason for the executive's departure; or (3) a news article indicates that the company was experiencing poor performance, the executive was less than 60 years old, no other article indicates that the executive had taken a position elsewhere, and no other article cited health, family or death as the reason for the executive's departure. All other turnover is considered "normal" turnover.

Neither of our turnover measures is a pristine characterization of the phenomenon that we wish to capture. In particular, we would like to be able to identify instances in which an executive has departed his position involuntarily. Our first measure, i.e., all departures, undoubtedly includes a significant number of voluntary departures. Thus, this measure will be an overstatement of the number we would like to have. However, if the rate of voluntary departures is constant before and after Cadbury, any differential in the rate of total turnover will represent a change in involuntary turnover such that our total turnover measure will capture any change in the rate of forced turnover. Even then, of course, any effect will be estimated with noise and the significance level of the effect will be downwardly biased.

Our second measure of turnover, i.e., "forced" turnover, will embed a different type of measurement error. Because our classification system is based on secondary sources, i.e., news accounts, any modifications in the way in which top management changes are reported through time could give rise to misclassifications. Of course, depending upon the way in which the practice of reporting top management turnover changed, any modification may lead to either an over- or under-statement of forced turnover. Our hope is that by using three sources to cross-reference turnover events, we have minimized the instances in which we have misclassified turnover due to a change in reporting practices. 
We are interested in the relationship between top management turnover and corporate performance. In our tests, we employ both accounting earnings and stock returns data to measure performance. Specifically, as our measure of accounting earnings, we use 3-year average industry-adjusted return on assets (IAROA). For each year, for each firm in the sample, we calculate ROA as earnings before depreciation, interest and taxes (EBDIT) divided by beginning of the year total assets. Then for each firm with the same Financial Times Industrial Classification as the firm in our sample, we calculate ROA in the same way. Next, each year, for each Industrial Classification group, we determine the median ROA. IAROA is calculated by subtracting the industry median ROA from the sample firm's ROA for each of the three years prior to a turnover event. The simple average of these three IAROAs is in our measure of accounting performance.

As our measure of stock price performance, we calculate market model cumulative excess returns (CERs) where market model parameters are estimated over a 280 trading-day period beginning 30 days after the announcement of the change in management. The valueweighted FTSE All Share Index is used as the market return. CERs are computed using daily returns beginning 36 calendar months prior to, and ending 2 days prior to, the announcement of the change in top management.

\section{Characteristics of the Sample}

To conduct our analysis, we split management turnover along two dimensions. First, for the full sample, we split turnover events into pre- and post-Cadbury time periods. The pre-Cadbury time period includes all top management turnover during 1989 through 1992. 
The post-Cadbury time period includes all turnover during 1993 through 1996. Descriptive data for these two samples are presented in the first column of Table I.

Second, we classify the observations according to whether the firm that experienced the turnover was (or was not) in compliance with the two key provisions of the Code. This second classification scheme gives rise to three sets of firms. The first set includes those firms that were in compliance with the Code for each year that the firm is in our sample (hereafter, the "always-in-compliance" set, 150 firms). The second set includes those firms that came into compliance with the Code during a year in which the firm was in our sample (hereafter, the "adopted-Cadbury" set, 288 firms). The third set includes those firms that were never in compliance with the Code during any year in which the firm was in our sample (hereafter, the "never-in-compliance" set, 22 firms). Descriptive data for the first and third sets are split into pre- and post-Cadbury time periods. These data are presented in columns two and four of Table I. Descriptive data for the second set of firms (i.e., the adoptedCadbury set) are split into pre- and post-Cadbury adoption time periods (i.e., y-4 to $y-1$ and $y+1$ to $y+4$, where $y$ equals the year in which the firm came into compliance with the Code). These data are presented in column three of Table I.

Panel A of Table I presents the market value of equity, total assets, and leverage for each set of firms. If there is anything remarkable in these data, it is the similarity across the various sets of firms and time periods along these dimensions. For example, the pre-Cadbury mean book value of assets for the 3 sets of firms is $£ 148.8 \mathrm{~m}, £ 150.1 \mathrm{~m}$ and $£ 146.8 \mathrm{~m}$, respectively. These data exemplify the commonality of data across the sets of firms.

Panel B presents the fraction of shares owned by each of three ownership categories: the top executive, the board of directors including the top executive, and institutional 
investors. The table also gives the number of block shareholders. Regardless of the category of investor, the fraction of shares held by that category is essentially unchanged from before to after Cadbury. On average, for the full sample, the top executive owns $1 \%$ of the stock, aggregate board ownership is approximately $2.25 \%$, institutional owners hold approximately $11 \%$ of the shares, and the typical firm has 2 or 3 blockholders. On these dimensions, the always-in-compliance set and the adopted-Cadbury set are similar to the full sample and to each other. However, the never-in-compliance set has significantly more ownership by the top executive (roughly 5\% vs. $1 \%$ ), significantly greater board ownership (roughly $9 \%$ vs. $2.5 \%$ ), significantly lower institutional ownership (roughly $6 \%$ vs. $11 \%$ ), and fewer blockholders than the other two sets. Apparently, firms with greater "inside" ownership of shares are less likely to adopt the Cadbury Code.

Panel C presents data on the composition of the board. Not surprisingly, there is considerable variation before and after Cadbury and across the various sets of firms. For the full set of firms, prior to Cadbury, the Chairman of the Board also held the position of top manager in $36.5 \%$ of the companies; after Cadbury, that fraction drops to $15.4 \%$. Of course, most of this change is due to the set of companies that came into compliance with the Code during the period of our study. For this set, prior to Cadbury, in $39 \%$ of the firms, a single individual held the position of Chairman and CEO; after adoption of Cadbury, of course, in none of these companies did a single individual hold both positions.

As regards, outside directors, for the full sample, prior to Cadbury, $35.3 \%$ of directors were outsiders; after Cadbury, the figure increased to $46.0 \%$. Almost all of this increase occurred among companies that came into compliance with the Code during the period of our study. For this set of firms, the fraction of outsiders increased from $26.1 \%$ before adoption of 
Cadbury to $46.6 \%$, afterward. For the always-in-compliance set, the percentage of outside directors prior to Cadbury, $48.6 \%$ was nearly identical to the percentage afterward, $48.5 \%$.

Finally, according to Panel C, most of the increase in outside directors came about by means of increasing the board size as opposed to replacing inside directors with outsiders. The median board increased by two members, from 5 to 7 directors, and most of this increase occurred among the adopted-Cadbury set of companies.

\section{Management Turnover}

What is clear from our analysis thus far is that the Cadbury Committee's recommendations had considerable impact on the size and composition of boards of directors, and on the number of firms in which one individual holds the titles of Chairman and CEO. The question to which we now turn is - - what impact, if any, have these changes had on top management turnover?

\section{A. Incidence and Rate of Top Management Turnover}

Panel A of Table II presents the incidence and rates of turnover in the top executive for the full sample, the always-in-compliance set, the adopted-Cadbury set, and the never-incompliance set. For the full sample, the always-in-compliance set, and the never-incompliance set, the turnover statistics are split into two four-year periods: a pre-Cadbury period (1989 through 1992) and a post-Cadbury period (1993 through 1996). For the adopted-Cadbury set, the turnover statistics are split into two four-year periods surrounding the year in which the firm came into compliance with the key provisions of the Code. The incidence of turnover is the number of instances in which we identified a change in the top executive. The rate of turnover is an annualized rate calculated as the incidence of turnover 
divided by the sample size divided by four years. The first two rows of Panel A present data on all turnover in the top executive and the second two rows present data on forced turnover in the top executive. Panel B parallels Panel A, except that Panel B contains the incidence and rates of turnover for the top management team excluding the top executive.

The incidence (and rate) of turnover in the top executive increased significantly from before to after Cadbury. This increase in turnover is due to an increase in what we have classified as forced turnover. For example, for the full sample, the rate of top executive turnover increased by $1.23 \%$ (i.e., from $6.48 \%$ to $7.71 \%$ ), and the rate of forced turnover increased by $1.20 \%$ (i.e., from $3.10 \%$ to $4.30 \%$ ). Furthermore, the increase in turnover in the top executive is concentrated in the adopted-Cadbury set of firms. For this set of firms, the rate of top executive turnover increased by $1.57 \%$ (i.e., from $7.24 \%$ to $8.87 \%$ ), and the rate of forced turnover increased by $2.27 \%$ (i.e., $2.71 \%$ to $4.98 \%$ ). For the always-in-compliance set, the rate of turnover and the rate of forced turnover is essentially unchanged from before to after Cadbury. For the never-in-compliance set, the rate of turnover declined modestly from before to after Cadbury, however, given the small sample size, we are inclined not to place too much weight to this result. Thus, the increase in turnover of the top executive following Cadbury is primarily attributable to those firms that adopted the key provisions of the Code of Best Practice.

From Panel B, for the full sample of firms, for the top management team excluding the top executive, the rate and incidence of all turnover increased from before to after Cadbury, albeit the increase is not statistically significant according to conventional standards ( $p$-value $=0.15$ ). However, for the adopted-Cadbury set, the incidence and rate of turnover is statistically significant. For this set of firms, the rate of turnover in the top team excluding the 
top executive increased by $1.27 \%$ (i.e., from $4.34 \%$ to $5.61 \%$ ). For the always-in-compliance and never-in-compliance sets of firms, the rate of turnover in the top team is essentially unchanged.

The picture that emerges from forced turnover in the top management team excluding the top executive is less clear-cut. For the full sample, the incidence and rate of forced turnover increases by statistically significant magnitudes from before to after Cadbury. Furthermore, the incidence and rate of forced turnover increased for the adopted-Cadbury set from before to after Cadbury and the increase is close to significant at conventional levels ( $\mathrm{p}$ value $=0.12$ ). The fly in the ointment resides in the always-in-compliance set. For this set of firms, which were already in compliance, the incidence and rate of forced turnover does increase by a statistically significant margin. Presumably that increase cannot be attributed to the Cadbury Committee's recommendations.

Turnover data for the top executive are consistent with an argument that the Cadbury Committees' recommendations have increased the quality of board oversight. That is, turnover, especially forced turnover, in the top executive position has increased and that increase is concentrated in the set of firms that adopted the key provisions of the Code of Best Practice. The apparent clear-cut connection between top executive turnover and the Cadbury Committee's recommendations is less clear-cut for other members of the top executive team. The attenuation of that connection could be due to either of two phenomena: Either increased board oversight following Cadbury focused on the top executive or the reporting of turnover for second-tier managers is not as thorough as that for the top executive.

Of course, it could be that the increased management turnover that we have documented following Cadbury is random across firms. The pertinent issue for our purposes 
is whether turnover is correlated with corporate performance. That is, are the "right" managers being replaced? That is the question to which we now turn.

\section{B. Relationship between Top Management Turnover and Corporate Performance}

Table III presents a first-pass look at the connection between turnover in the top executive position and corporate performance. The presentation in Table III follows the classification scheme used in Table II in that firms are classified according to their Cadbury adoption status and observations are classified according to whether they are pre- or postCadbury. The additional dimension provided by Table III is the firms' relative performance where performance is measured as three-year average IAROA or three-year CER as described in Section II. For example, to construct Panel A, for each calendar year, firms are ranked from lowest to highest on the basis of their prior three-year average IAROA. For each year, observations are then sorted into quartiles with quartile 1 containing the 115 firms with the lowest IAROA and quartile 4 containing the 115 firms with highest IAROA. Panel B parallels Panel A except that Panel B includes only forced turnover. Panels C and D parallel Panels A and B except that in Panels C and D performance is based on three-year prior CER.

Regardless of whether we consider all turnover or forced turnover, regardless of the performance measure used, and regardless of which set of firms we consider, the incidence and rate of turnover increases as we move from the best to the poorest performing firms both before and after Cadbury. That is, turnover of the top executive is concentrated in the poorest performing firms both before and after Cadbury. To the extent that there is any difference across the panels, it is that forced turnover is especially concentrated in the poorest performing quartiles.

The data also hint that the increase in top executive turnover from before to after 
Cadbury that we documented in Table II is due to an increase in turnover in the lowest two performance quartiles in the adopted-Cadbury set of firms. For example, for this set of firms in Panel $\mathrm{A}$, the rate of turnover in Quartiles 1 and 2 increased by 6.6\% (i.e., from $9.0 \%$ to $15.6 \%$ ) and $2.8 \%$ (i.e., from $7.6 \%$ to $10.4 \%$ ) respectively from before to after adoption of Cadbury. Both of these increases have p-values less than 0.05 . In comparison, for the always-in-compliance set, in the same bottom two quartiles, the rate of turnover is essentially unchanged from before to after Cadbury.

The data for turnover in the top management team excluding the top executive (not shown in a table) generally show any increase in the incidence and rate of turnover as we move from the best to the poorest performing firms, however, the relationship is not as linear as shown in Table III for top executives. ${ }^{7}$ For example, in the top two IAROA quartiles of the full sample of firms for forced turnover, the rate of turnover in the top team excluding the top executive is $1.0 \%$. For the bottom two quartiles, the rate of forced turnover is $5.1 \%$. However, the rate of turnover increases slightly from $4.25 \%$ to $6.1 \%$ as we move from the quartile 1 to quartile 2 .

\section{Multivariate Analysis of the Relationship between Top Management Turnover and Corporate Performance}

The final questions, to which we now turn, are whether the relationship between turnover and performance is statistically significant and whether the sensitivity of turnover to performance is greater following Cadbury. To answer that question and to control for other factors that may influence managerial turnover, we estimate logit regressions. Initially, we estimate regressions for the top executive in which the dependent variable is 1 if a firm

\footnotetext{
${ }^{7}$ These data in tabular form are available from the authors upon request.
} 
experiences turnover in the top executive during a calendar year and zero otherwise. We estimate separate regressions for all turnover and for forced turnover. We estimate separate regressions using three-year prior IAROA and three-year CER as our performance measures. We include four control variables in each regression: fraction of shares owned by directors, fraction of shares owned by institutional investors, number of block shareholders, and log of total assets. (Subsequently, we estimate the same regressions for turnover in the top team excluding the top executive.)

The results of our regressions for the top executive are presented in Tables IV and V. In Table IV, the performance variable is IAROA. In Table V, the performance variable is CER. Panel A of each table presents regressions with all top executive turnover as the dependent variable and Panel B presents regressions with forced turnover as the dependent variable. Each panel contains five regressions. Each regression includes either IAROA or CER as an independent variable. In each regression, the coefficient of that variable is negative and, with one exception, each has a p-value of less than 0.05 . Thus, top executive turnover is significantly negatively correlated with corporate performance: the poorer the firm's performance, the greater the likelihood that the top executive will depart his position.

Of the four control variables, only the fraction of shares owned by directors regularly has a p-value less than 0.10 . The coefficient of this variable is always negative which indicates that after controlling for performance, increased share ownership by the board reduces the likelihood that the top executive will depart his position.

We now turn to the effect of Cadbury on top executive turnover and the effect of Cadbury on the relationship between top executive turnover and corporate performance. To begin, the first regression in each panel is estimated for the full sample of firms and includes 
an indicator variable (Dum for 1993-96) which takes a value of 0 for all observations before January 1993 (the pre-Cadbury period) and a value of 1 for all observations after that date (the post-Cadbury period). In each regression, the coefficient of the indicator variable Dum for $1993-96$ is positive with p-values ranging from 0.03 to 0.11 . Thus, even after controlling for corporate performance, turnover is higher in the post-Cadbury period. However, as we noted in Table III, increased turnover appears to be attributable to the set of firms that came into compliance with the Cadbury Committees' recommendations (the adopted-Cadbury set) as opposed to those firms that were always in compliance with Cadbury.

To determine whether the Cadbury/turnover relationship is due to a general phenomenon affecting all firms or whether it is due specifically to a change in board structures traceable to the Cadbury recommendations, we estimate the regression separately for the always-in-compliance set of firms and for the adopted-Cadbury set. The only difference in the regressions is that for the adopted-Cadbury set, the indicator variable (Dum for Adopt) takes on a value of 0 in all years prior to the year in which the firm came into compliance with the Code of Best Practice and a value of 1 for all subsequent years. These are the second and third regressions in each panel.

For the always-in-compliance set, the coefficient of the Cadbury Dummy variable (Dum for Adopt) is always positive, but the p-values range from 0.79 to 0.92 . Thus, introduction of the Cadbury Report had a trivial impact, if any, on the rate of turnover among top executives in firms that were already in compliance with the key provisions of the Code. For the adopted-Cadbury set, the coefficient of the indicator variable Dum for Adopt is always positive with p-values ranging from 0.06 to 0.09 . Additionally, the magnitude of the coefficient is 10 times the magnitude of the coefficient of the Cadbury Dummy (Dum for 
1993-96) for the always-in-compliance set. Thus, the publication of the Code of Best Practice did not have an impact, per se, on the rate of turnover among top UK executives; rather the effect was concentrated among those firms that altered their board structures to comply with the Code. This is not to say that the rate of turnover among top executives in firms that were always-in-compliance was "too low" either before or after Cadbury. The data only show that the rate of turnover for these firms did not change between the pre- and post-Cadbury periods. In comparison, the rate of turnover increased significantly among firms that came into compliance with the Cadbury recommendations during the period of this study.

To determine whether the increase in turnover is correlated with performance, we estimate a regression with the adopted-Cadbury set of firms that includes the Adopted Cadbury Dummy (Dum for Adopt) and the Adopted Cadbury Dummy interacted with our measures of performance (either IAROA or CER) along with our measures of performance (Dum for Adopt x Perform) and our four control variables. These are the key regressions of our analysis and are reported as the fourth regression in each panel.

The coefficient of the interaction variable will indicate whether the increase in turnover among firms that adopted Cadbury is randomly distributed across those firms or is concentrated among the poorest performing firms. In each regression, the coefficient of the interaction variable is negative with p-values ranging from 0.02 to 0.08 . Additionally, the coefficient of the Adopted Cadbury Dummy (Dum-for-Adopt) is reduced by $75 \%$ and now has p-values ranging from 0.66 to 0.76 . These results indicate that the increase in top executive turnover is not random, rather it is (inversely) correlated with performance: After controlling for performance, the likelihood that the top executive will depart his position is greater once a poorly performing firm comes into compliance with the key provisions of the 
Code of Best Practice. The answer to the question of whether the "right" managers are leaving the firms appears to be yes, assuming, of course, that our measures of performance properly identify the right managers.

So far we have employed an indicator variable to capture the key provisions of the Code of Best Practice. A further question is - - which of the key provisions is responsible for the increased sensitivity of turnover to corporate performance? To address that question, we estimate a final regression with the adopted-Cadbury set of firms in which we include the fraction of outside directors, an interaction between the fraction of outsiders and our measures of corporate performance (either IAROA or CER), an indicator variable to identify observations in which the positions of the Chairman and CEO are held by a single individual (1) or by two individuals (0), and an interaction between this indicator variable and our measures of corporate performance. These variables are designed to capture the changes brought about by the Code of Best Practice. Because, as we show in Table I, adoption of the Code led to a general increase in board size, we also include the number of directors and an interaction between the number of directors and our measure of performance. These regressions, which also include a performance measure, Dum-for-Adopt, and the four control variables, are shown as the fifth regression in each panel.

According to the regressions, when the board composition and Chairman/CEO variables are included, the coefficients of the interaction of the Dum-for-Adopt and our measures of performance are not significant (p-values range from 0.59 to 0.96 ). Additionally, the coefficient of the fraction of outsiders on the board is positive, albeit not significant, in each regression (p-values range from 0.27 to 0.38 ). More interestingly, the coefficients of the interaction between the fraction of outsiders and our measures of performance are always 
negative with p-values that range from 0.07 to 0.10 . In contrast, in none of the regressions does the coefficients of the dummy for the CEO/chairman or the coefficient of the interaction of this variable with our measures of performance begin to approach statistical significance (p-values range from 0.88 to 0.94 ).

Apparently, the increased sensitivity of turnover to corporate performance for the adopted-Cadbury set (and the contemporaneous loss in significance of the interaction of Dum-for-Adopt with performance) is attributable to the increase in the fraction of outside directors. Splitting the responsibilities of the Chairman and CEO between two individuals appears to have no effect on the rate of turnover in the top executive.

Two further observations are worth making. The coefficient of board size is always negative, which indicates that turnover is less likely, the larger the board; however, with pvalues that range from 0.20 to 0.37 , this variable is not significant at traditionally accepted levels. The more interesting variable is the interaction of board size with our measures of performance. The coefficients of this variable are also always negative and have p-values that range from 0.07 to 0.10 . Thus, the sensitivity of turnover to performance is lower the larger the board. Or to put it slightly differently, firms with smaller boards show more sensitivity to performance (in terms of turnover in the top executive) than do firms with larger boards.

The regressions reported in Tables IV and V for turnover in the top executive are also estimated for turnover in the top management team excluding the top executive. The signs of the coefficients for these regressions (not shown in a table) are identical to those of Tables IV and $\mathrm{V}$, however, the p-values of the variables are not significant at traditional levels. For example, the sign of the Cadbury 1993-96 dummy variable is positive with p-values that range from 0.16 to 0.20 . Similarly, the sign on the Dum-for-Adopt variable is also positive in 
each regression, but has p-values that range from 0.17 to 0.24 . The coefficient for the interaction of Dum-for-Adopt and our measures of performance in the same regression is always negative with p-values that range from 0.15 to $0.26 .^{8}$ In short, the regressions for turnover in the top management team excluding the top executive are consistent with those of turnover in the top executive, but the levels of statistical significance are much weaker.

\section{Commentary and Conclusions}

As we noted at the outset, we view this study as making contributions in the small and the large of corporate governance and of the connection between management turnover and corporate performance. From a narrow perspective, we have analyzed in detail the effect of the Cadbury Committee's key recommendations on the structure of UK boards of directors and on the impact of these recommendations on the connection between top management turnover and corporate performance. We document a general increase in the size of corporate boards, an increase in the fraction of outside directors, and an increase in the number of firms in which the positions of CEO and chairman are held by two different individuals following publication of the Cadbury Committee's recommendations in December 1992. We also document an increase in the rate of top management turnover following publication of the Cadbury Report and that this increase is concentrated among firms that came into compliance with the key provisions of the Code of Best Practice during the period of our study. We further document a significant (negative) correlation between top management turnover and corporate performance both before and after the Cadbury Report: the poorer the performance, the higher the rate of turnover. Among firms that came into compliance with the Code during

\footnotetext{
${ }^{8}$ The results of these regressions are available from the authors upon request.
} 
the period of our study, we find an increase in the correlation of turnover to corporate performance following their adoption of the Code. Finally, this increase in the sensitivity of turnover to performance appears to be due to the increase in the fraction of outside directors, rather than splitting the responsibilities of the CEO and chairman between two individuals.

Thus, when we refer to our findings as contributing to the small of corporate governance, we mean to say that our study examines the link between management turnover, corporate performance, and board structure in the specific context of the issuance and the implementation of the Cadbury Report. We do not mean to minimize the importance of our findings to the firms and investors involved nor to the global economy, after all the Code applies to all publicly-traded UK companies and the UK's GNP ranks 7th among all nations.

From a broader perspective, we mean to say that our results are likely to have implications beyond the confines of the Cadbury Report and add to the broader literature on management turnover, corporate performance, corporate governance and board structure. Prior studies on the relationship between top management turnover and corporate performance include Coughlan and Schmidt (1985), Franks and Mayer (1995), Gilson (1989), Huson, Parrino and Starks (1998), Jensen and Murphy (1990), Kang and Shivdasani (1995) and Kaplan (1994a, b), Martin and McConnell (1991), Mikkelson and Partch (1997), Morck, Shleifer and Vishny (1989), Murphy and Zimmerman (1993), Warner, Watts and Wruck (1988) and Weisbach (1988). These studies cover various time periods beginning in 1962 and encompass Japan, the US, and the UK. Each of these studies reports a negative and significant correlation between top management turnover and at least one measure of corporate performance, either accounting profitability or stock returns. Our results complement those of earlier studies and add to them in that we document a negative and 
significant correlation between top management turnover and corporate performance and we document an increase in the sensitivity of turnover to performance following publication of the Cadbury Report and the adoption of the Code of Best Practice by UK companies.

Our study also complements and adds to the literature on board composition and corporate performance. Bhagat and Black (1998) dichotomize research on this topic into two categories: (1) studies of whether board composition determines the way in which boards accomplish discrete tasks, such as hiring and firing top management, responding to hostile takeovers, setting CEO compensation, and so forth and (2) studies of how board composition influences the firm's overall profitability. Our study fits the former category.

Prior studies of board composition and management turnover provide mixed results. Weisbach (1988) studies 367 publicly-traded non-financial US companies over the period 1974 through 1983 . He determines that CEO turnover is more highly negatively correlated with performance (measured with both accounting earnings and stock returns) in firms with outsider dominated boards. Kang and Shivdasani (1995) examine 270 publicly-traded nonfinancial Japanese companies over the period 1985 through 1990 . Contrary to Weisbach, they find that the sensitivity of turnover to performance is unrelated to the fraction of outside directors. ${ }^{9}$

Our results are consistent with Weisbach in that we determine that, among poorly performing firms, top management turnover increases as the fraction of outside board members increases. Like Weisbach, our results are contrary to those of Kang and Shivdasani and that difference may very well be attributable to cross-country differences in the role of

\footnotetext{
${ }^{9}$ Mikkelson and Partch (1997) examine 200 publicly-traded US companies over the period 1984 through 1993. They find no relationship between the probability of management turnover and the fraction of outside directors on the board. However, they do not examine the sensitivity of the relationship between turnover and
} 
boards and outside directors. If so, the US and the UK apparently are more similar to each other on this dimension than is either one to Japan.

As we noted, our study fits into the first category of research identified by Bhagat and Black (1998). Having examined the impact of the Cadbury Committee's recommendations on one specific board task, in a subsequent study, we intend to turn our attention to the second category by examining the effect of the Committee's recommendations on overall corporate performance.

performance to the fraction of outside directors. Thus their study and ours are not directly comparable. 


\section{References}

Agrawal, A., and C. R. Knoeber, 1996, Firm performance and mechanisms to control agency problems between managers and shareholders, Journal of Financial and Quantitative Analysis, 31, 377-397.

Bhagat, S., and B. Black, 1996, Do independent directors matter?, Working Paper, University of Colorado and Columbia Law School.

Bhagat, S., and B. Black, 1998, The uncertain relationship between board composition and firm performance, Working Paper, University of Colorado and Columbia Law School.

Byrd, J. W., and K. A. Hickman, 1992, Do outside directors monitor managers? Evidence from tender offers, Journal of Financial Economics, 32, 195-221.

Cadbury, Sir A., 1992, Committee on Financial Aspects of Corporate Governance, HMSO.

Cotter, J., A. Shivdasani, and M. Zenner, 1997, Do independent directors enhance target shareholder wealth during tender offers?, Journal of Financial Economics, 43, 195-218.

Coughlan, A. T., and R. M. Schmidt, 1985, Executive compensation, management turnover, and firm performance, Journal of Accounting and Economics, 7, 43-66.

Denis, D., and D. Denis, 1995, Performance changes following top management dismissals, Journal of Finance, 50, 1029-1057.

Denis, D., and A. Sarin, 1999, Ownership and board structure in publicly traded corporations turnover, Journal of Finance, forthcoming.

Franks, J., and C. Mayer, 1996, Hostile takeovers and the correction of managerial failure, Journal of Financial Economics, 40, 163-181.

Gilson, S., 1989, Management turnover and financial distress, Journal of Financial Economics, 25, 241-262.

Hermalin, B., and M. Weisbach, 1998, Endogenously chosen boards of directors and their monitoring of the CEO, American Economic Review, 88, 96-118.

Huson, M., R. Parrino, and L. T. Starks, 1998, Internal monitoring mechanisms and CEO turnover: A long term perspective, unpublished manuscript (University of Alberta, Edmonton, $\mathrm{AB})$.

Jensen, M. C., and K. J. Murphy, 1990, Performance pay and top management incentives, Journal of Political Economy, 98, 225-264. 
Kang, J., and A. Shivdasani, 1995, Firm performance, corporate governance, and top executive turnover in Japan, Journal of Financial Economics, 38, 29-58.

Kaplan, S. N., 1994a, Top executives, turnover and firm performance in Germany, Journal of Law, Economics and Organization, 10, 142-159.

Kaplan, S. N., 1994b, Top executive rewards and firm performance: A comparison of Japan and the United States, Journal of Political Economy, 102, 510-546.

Kaplan, S. N., and D. Reishaus, 1990, Outside directorships and corporate performance, Journal of Financial Economics, 27, 389-410.

Kini, O., W. Kracaw, and S. Mian, 1995, Corporate takeovers, firm performance, and board composition, Journal of Corporate Finance, 1, 383-412.

Klein A., 1997, Affiliated directors: Puppets of management or effective directors, Working Paper, New York University.

Kole, S. R., and K. M. Lehn, 1999, Deregulation and the adaption of governance structures: The case of the US airline industry, Journal of Financial Economics, 52, 79-117.

Martin, K., and J. J. McConnell, 1991, Corporate performance, corporate takeovers, and management turnover, Journal of Finance, 46, 671-687.

Mikkelson, W., and M. Partch, 1997, The decline of takeovers and disciplinary management turnover, Journal of Financial Economics, 44, 205-228.

Morck, R, A. Shleifer, and R. W. Vishny, 1989, Alternative mechanisms for corporate control, American Economic Review, 79, 842-852.

Murphy, K. J., and J. L. Zimmerman, 1993, Financial performance surrounding CEO turnover, Journal of Accounting and Economics, 16, 273-315.

Rosenstein, S., and J. G. Wyatt, 1990, Outside directors, board independence, and shareholder wealth, Journal of Financial Economics, 26, 175-191.

Shivdasani, A., 1993, Board composition, ownership structure and hostile takeovers, Journal of Accounting and Economics, 16, 167-198.

Warner, J. B., R. L. Watts, and K. H. Wruck, 1988, Stock prices and top management changes, Journal of Financial Economics, 20, 461-492.

Weisbach, M., 1988, Outside directors and CEO turnover, Journal of Financial Economics, $20,431-460$. 
Yermack, D., 1996, Higher market valuation of companies with small board of directors, Journal of Financial Economics, 40, 185-212.

You, V., R. Caves, M. Smith, and J. Henry, 1986, Mergers and bidders' wealth: Managerial and strategic factors, in Lacy Glenn Thomas, III ed., The Economics of Strategic Planning: Essays in Honour of Joel Dean, pp. 201-221. 


\section{Table I}

\section{Financial, Ownership, and Board Characteristics of UK Companies over 1989 through 1996}

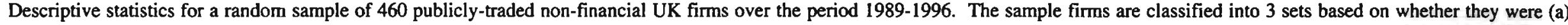

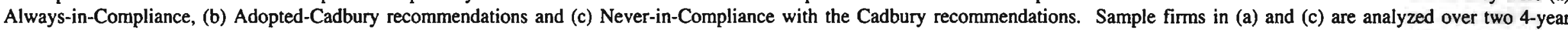

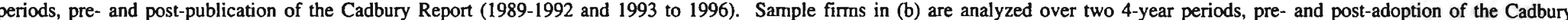

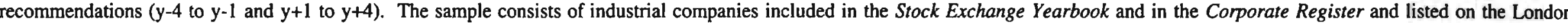

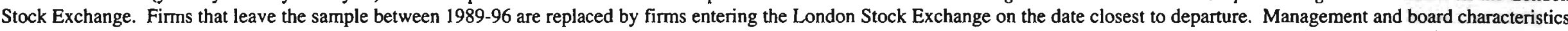
are from the Corporate Register and are cross-checked with information at UK Companies House. Accounting information and share prices are from Datastream.

\begin{tabular}{|c|c|c|c|c|c|c|c|c|c|c|c|c|}
\hline & \multicolumn{3}{|c|}{ Sample Firms } & \multicolumn{3}{|c|}{ Always-in-Compliance } & \multicolumn{3}{|c|}{ Adopted-Cadbury } & \multicolumn{3}{|c|}{ Never-in-Compliance } \\
\hline & Years & Mean & (Median) & Years & Mean & (Median) & Years & Mean & (Median) & Years & Mean & (Median) \\
\hline & & \multicolumn{8}{|c|}{ Panel A: Financial Characteristics } & \\
\hline & \multicolumn{3}{|c|}{$\underline{N}=460$} & \multicolumn{3}{|c|}{$\underline{N}=150$} & \multicolumn{3}{|c|}{$\underline{N}=288$} & \multicolumn{3}{|c|}{$\underline{N}=22$} \\
\hline Market Value of Equity & $1989-92$ & $523.4^{* *}$ & $(255.96)^{* *}$ & $1989-92$ & $539.2^{* *}$ & $(256.74)^{* *}$ & $y-4$ to $y-1$ & $521.9^{* *}$ & $(255.61)^{* *}$ & $1989-92$ & 511.4 & $(254.11)$ \\
\hline ( $£$ million) & $1993-96$ & 717.2 & $(272.94)$ & $1993-96$ & 704.4 & $(269.32)$ & $y+1$ to $y+4$ & 722.6 & $(273.91)$ & $1993-96$ & 579.3 & $(258.86)$ \\
\hline Book Value of Assets & $1989-92$ & $149.2^{*}$ & $(50.8)$ & $1989-92$ & $148.8^{*}$ & $(48.8)$ & $y-4$ to $y-1$ & $150.1^{*}$ & $(50.7)$ & $1989-92$ & 146.8 & $(45.3)$ \\
\hline ( $£$ million) & $1993-96$ & 156.8 & $(56.7)$ & $1993-96$ & 155.6 & $(53.2)$ & $y+1$ to $y+4$ & 158.6 & $(58.7)$ & $1993-96$ & 150.7 & $(49.2)$ \\
\hline Liabilities/Assets & $1989-92$ & 0.501 & $(0.505)$ & $1989-92$ & 0.502 & $(0.493)$ & $y-4$ to $y-1$ & 0.500 & $(0.509)$ & $1989-92$ & 0.579 & $(0.582)$ \\
\hline & $1993-96$ & 0.509 & $(0.562)$ & $1993-96$ & 0.519 & $(0.538)$ & $y+1$ to $y+4$ & 0.503 & $(0.498)$ & $1993-96$ & 0.603 & $(0.597)$ \\
\hline
\end{tabular}

Panel B: Share Ownership

\begin{tabular}{|c|c|c|c|c|c|c|c|c|c|c|c|c|}
\hline Top Executive & $1989-92$ & 1.08 & $(1.01)$ & $1989-92$ & 1.07 & $(0.98)$ & $y-4$ to $y-1$ & 1.11 & $(1.05)$ & $1989-92$ & 5.37 & $(4.30)$ \\
\hline Ownership of Shares $(0 \%)$ & $1993-96$ & 1.04 & $(1.05)$ & $1993-96$ & 1.01 & $(0.99)$ & $y+1$ to $y+4$ & 1.10 & $(1.08)$ & $1993-96$ & 3.89 & (3.29) \\
\hline Board Ownership & $1989-92$ & 2.23 & (2.39) & $1989-92$ & 2.22 & $(2.23)$ & $y-4$ to $y-1$ & 2.23 & $(2.44)$ & $1989-92$ & 9.93 & (10.11) \\
\hline of Shares $(0 \%)$ & $1993-96$ & 2.24 & $(2.34)$ & $1993-96$ & 2.09 & $(1.96)$ & $y+1$ to $y+4$ & 2.25 & $(2.43)$ & $1993-96$ & 8.34 & $(9.27)$ \\
\hline Institutional & $1989-92$ & 10.70 & $(10.96)$ & $1989-92$ & 12.83 & $(12.60)$ & $y-4$ to $y-1$ & 9.79 & $(9.99)$ & 1989-92 & 6.45 & $(5.93)$ \\
\hline Ownership (0\%) & $1993-96$ & 11.35 & $(10.83)$ & $1993-96$ & 13.32 & $(13.01)$ & $y+1$ to $y+4$ & 11.09 & $(10.44)$ & $1993-96$ & 6.09 & $(5.99)$ \\
\hline Number of & $1989-92$ & 2 & (2) & $1989-92$ & 3 & $(2.04)$ & $y-4$ to $y-1$ & $2^{*}$ & $(2)^{*}$ & 1989-92 & 1 & (1) \\
\hline Blockholders & $1993-96$ & 3 & (3) & $1993-96$ & 3 & $(3.05)$ & $y+1$ to $y+4$ & 3 & (3) & 1993-96 & 1 & (1) \\
\hline
\end{tabular}


Table I - - continued

Panel C: Board Characteristics

\begin{tabular}{|c|c|c|c|c|c|c|c|c|c|c|c|c|}
\hline Percent with & $1989-92$ & $36.49^{*}$ & & 1989-92 & 0.00 & & $y-4$ to $y-1$ & $39.07^{* *}$ & & $1989-92$ & 42.17 & \\
\hline $\begin{array}{l}\text { Single Individual as } \\
\text { Chairman \& CEO }\end{array}$ & $1993-96$ & 15.43 & & $1993-96$ & 0.00 & & $y+1$ to $y+4$ & 0.00 & & $1993-96$ & 35.21 & \\
\hline Board Size & $\begin{array}{l}1989-92 \\
1993-96\end{array}$ & $\begin{array}{l}5.71 \\
7.29\end{array}$ & $\begin{array}{l}(5.00)^{*} \\
(7.00)\end{array}$ & $\begin{array}{l}1989-92 \\
1993-96\end{array}$ & $\begin{array}{l}6.69 \\
7.41\end{array}$ & $\begin{array}{l}(6.00) \\
(7.00)\end{array}$ & $\begin{array}{l}y-4 \text { to } y-1 \\
y+1 \text { to } y+4\end{array}$ & $\begin{array}{l}5.49^{*} \\
7.13\end{array}$ & $\begin{array}{l}(5.00)^{*} \\
(7.00)\end{array}$ & $\begin{array}{l}1989-92 \\
1993-96\end{array}$ & $\begin{array}{l}4.53 \\
5.02\end{array}$ & $\begin{array}{l}(4.00) \\
(5.00)\end{array}$ \\
\hline $\begin{array}{l}\text { Percentage of } \\
\text { Outside Directors }\end{array}$ & $\begin{array}{l}1989-92 \\
1993-96\end{array}$ & $\begin{array}{l}35.3^{* *} \\
46.0\end{array}$ & $\begin{array}{l}(36.9)^{* *} \\
(43.1)\end{array}$ & $\begin{array}{l}1989-92 \\
1993-96\end{array}$ & $\begin{array}{l}48.6 \\
48.5\end{array}$ & $\begin{array}{l}(43.4) \\
(45.8)\end{array}$ & $\begin{array}{l}y-4 \text { to } y-1 \\
y+1 \text { to } y+4\end{array}$ & $\begin{array}{l}26.1^{* *} \\
46.6\end{array}$ & $\begin{array}{l}(25.7)^{* *} \\
(40.6)\end{array}$ & $\begin{array}{l}1989-92 \\
1993-96\end{array}$ & $\begin{array}{l}17.9 \\
21.5\end{array}$ & $\begin{array}{l}(15.4) \\
(20.9)\end{array}$ \\
\hline
\end{tabular}

" and "denotes significance at the 0.01 and 0.05 levels respectively. 


\section{Table II}

\section{Incidence and Rates of Top Management Turnover in UK Companies, 1989 through 1996}

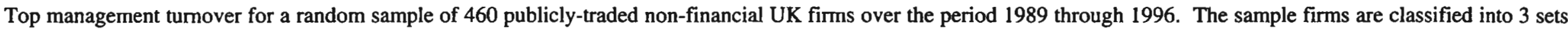

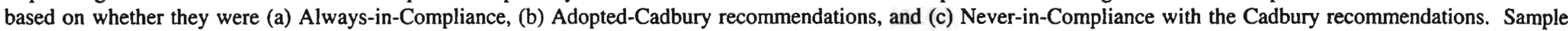

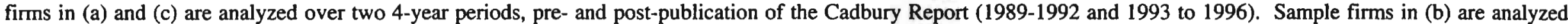

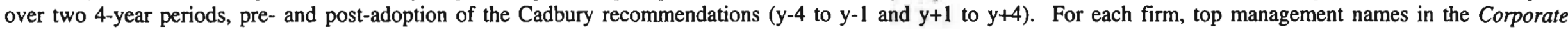

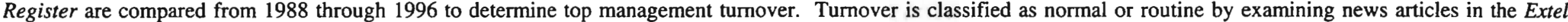
Weekly News Summaries, the Financial Times and Macarthy's News Information Service.

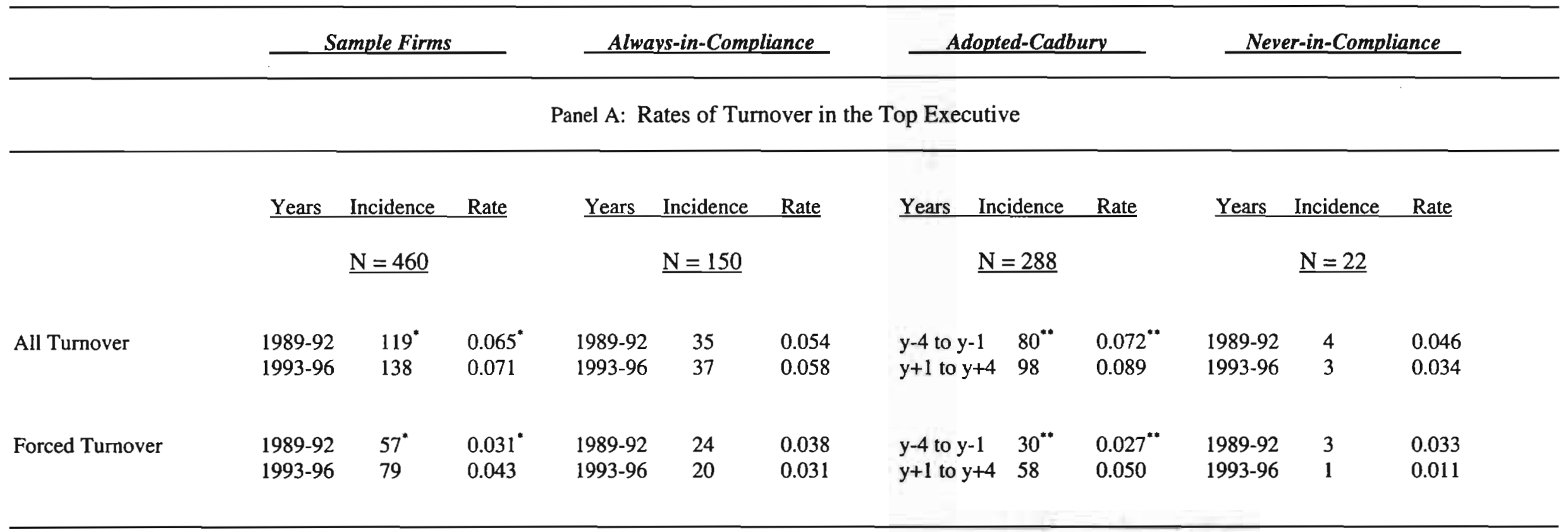

Panel B: Rates of Turnover in the Top Management Team excluding the Top Executive

\begin{tabular}{|c|c|c|c|c|c|c|c|c|c|c|c|c|}
\hline All Tumover & $\begin{array}{l}1989-92 \\
1993-96\end{array}$ & $\begin{array}{l}77 \\
90\end{array}$ & $\begin{array}{l}0.042 \\
0.049\end{array}$ & $\begin{array}{l}1989-92 \\
1993-96\end{array}$ & $\begin{array}{l}21 \\
22\end{array}$ & $\begin{array}{l}0.033 \\
0.034\end{array}$ & $\begin{array}{l}y-4 \text { to } y-1 \\
y+1 \text { to } y+4\end{array}$ & $\begin{array}{l}48^{*} \\
62\end{array}$ & $\begin{array}{l}0.043^{*} \\
0.056\end{array}$ & $\begin{array}{l}1989-92 \\
1993-96\end{array}$ & $\begin{array}{l}8 \\
6\end{array}$ & $\begin{array}{l}0.091 \\
0.068\end{array}$ \\
\hline Forced Turnover & $\begin{array}{l}1989-92 \\
1993-96\end{array}$ & $\begin{array}{l}48^{*} \\
66\end{array}$ & $\begin{array}{l}0.026^{*} \\
0.036\end{array}$ & $\begin{array}{l}1989-92 \\
1993-96\end{array}$ & $\begin{array}{l}6^{*} \\
16\end{array}$ & $\begin{array}{l}0.094^{*} \\
0.025\end{array}$ & $\begin{array}{l}y-4 \text { to } y-1 \\
y+1 \text { to } y+4\end{array}$ & $\begin{array}{l}37 \\
47\end{array}$ & $\begin{array}{l}0.033 \\
0.043\end{array}$ & $\begin{array}{l}1989-92 \\
1993-96\end{array}$ & $\begin{array}{l}5 \\
3\end{array}$ & $\begin{array}{l}0.054 \\
0.033\end{array}$ \\
\hline
\end{tabular}

${ }^{*}$ and ${ }^{\circ}$ denotes significance at the 0.01 and 0.05 levels respectively. 


\section{Table III}

\section{Top Executive Turnover in UK Firms Grouped by Quartiles of Performance over 1989 through 1996}

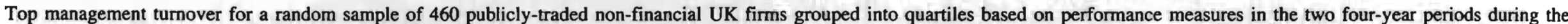

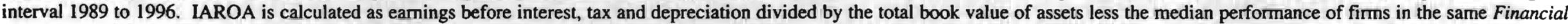

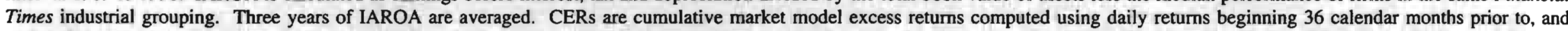

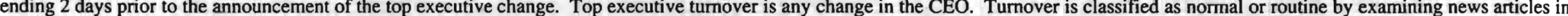

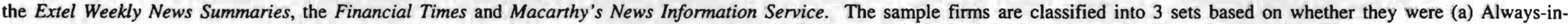

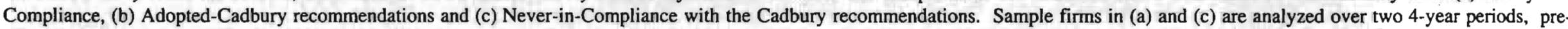

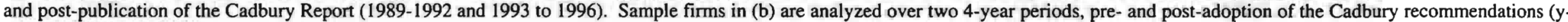
4 to $y-1$ and $y+1$ to $y+4)$.

\begin{tabular}{|c|c|c|c|c|}
\hline Interval & $\frac{\text { Quartile 1 }}{\text { (Lowest performance) }}$ & Quartile 2 & Quartile 3 & $\frac{\text { Quartile } 4}{\text { (Highest performance) }}$ \\
\hline
\end{tabular}

Panel A: Top Executive Turnover by Quartiles of Industry- and Size-adjusted IAROA

\begin{tabular}{|c|c|c|c|c|c|c|c|c|c|}
\hline & $\underline{\text { Years }}$ & Incidence & $\underline{\text { Rate }}$ & Incidence & $\underline{\text { Rate }}$ & Incidence & $\underline{\text { Rate }}$ & Incidence & $\underline{\text { Rate }}$ \\
\hline All sample firms & $\begin{array}{l}1989-1992 \\
1993-1996\end{array}$ & $\begin{array}{l}49 \\
66\end{array}$ & $\begin{array}{l}0.107^{* *} \\
0.143\end{array}$ & $\begin{array}{l}33 \\
41\end{array}$ & $\begin{array}{l}0.072 \\
0.089\end{array}$ & $\begin{array}{l}24 \\
21\end{array}$ & $\begin{array}{l}0.052 \\
0.046\end{array}$ & $\begin{array}{l}13 \\
10\end{array}$ & $\begin{array}{l}0.028 \\
0.022\end{array}$ \\
\hline (a) Always in compliance & $\begin{array}{l}1989-1992 \\
1993-1996\end{array}$ & $\begin{array}{l}21 \\
20\end{array}$ & $\begin{array}{l}0.140 \\
0.133\end{array}$ & $\begin{array}{l}10 \\
10\end{array}$ & $\begin{array}{l}0.067 \\
0.067\end{array}$ & $\begin{array}{l}3 \\
6\end{array}$ & $\begin{array}{l}0.020 \\
0.040\end{array}$ & $\begin{array}{l}1 \\
1\end{array}$ & $\begin{array}{l}0.007 \\
0.007\end{array}$ \\
\hline (b) Adopted compliance & $\begin{array}{l}y-4 \text { to } y-1 \\
y+1 \text { to } y+4\end{array}$ & $\begin{array}{l}26 \\
45\end{array}$ & $\begin{array}{l}0.090^{* *} \\
0.156\end{array}$ & $\begin{array}{l}22 \\
30\end{array}$ & $\begin{array}{l}0.076^{*} \\
0.104\end{array}$ & $\begin{array}{l}20 \\
14\end{array}$ & $\begin{array}{l}0.069 \\
0.049\end{array}$ & $\begin{array}{l}12 \\
9\end{array}$ & $\begin{array}{l}0.042 \\
0.031\end{array}$ \\
\hline (c) Never in compliance & $\begin{array}{l}1989-1992 \\
1993-1996\end{array}$ & $\begin{array}{l}2 \\
1\end{array}$ & $\begin{array}{l}0.091 \\
0.045\end{array}$ & $\begin{array}{l}1 \\
1\end{array}$ & $\begin{array}{l}0.045 \\
0.045\end{array}$ & $\begin{array}{l}1 \\
1\end{array}$ & $\begin{array}{l}0.045 \\
0.045\end{array}$ & $\begin{array}{l}0 \\
0\end{array}$ & $\begin{array}{l}0.000 \\
0.000\end{array}$ \\
\hline
\end{tabular}

Panel B: Forced Top Executive Tumover by Quartiles of Industry- and Size-adjusted IAROA

\begin{tabular}{|c|c|c|c|c|c|c|c|c|c|}
\hline All sample firms & $\begin{array}{l}1989-1992 \\
1993-1996\end{array}$ & $\begin{array}{l}33 \\
47\end{array}$ & $\begin{array}{l}0.072^{*} \\
0.102\end{array}$ & $\begin{array}{l}15 \\
25\end{array}$ & $\begin{array}{l}0.033 \\
0.054\end{array}$ & $\begin{array}{l}9 \\
7\end{array}$ & $\begin{array}{l}0.020 \\
0.015\end{array}$ & $\begin{array}{l}0 \\
0\end{array}$ & $\begin{array}{l}0.000 \\
0.000\end{array}$ \\
\hline (a) Always in compliance & $\begin{array}{l}1989-1992 \\
1993-1996\end{array}$ & $\begin{array}{l}15 \\
15\end{array}$ & $\begin{array}{l}0.100 \\
0.100\end{array}$ & $\begin{array}{l}6 \\
5\end{array}$ & $\begin{array}{l}0.040 \\
0.033\end{array}$ & $\begin{array}{l}3 \\
0\end{array}$ & $\begin{array}{l}0.020 \\
0.000\end{array}$ & $\begin{array}{l}0 \\
0\end{array}$ & $\begin{array}{l}0.000 \\
0.000\end{array}$ \\
\hline (b) Adopted compliance & $\begin{array}{l}y-4 \text { to } y-1 \\
y+1 \text { to } y+4\end{array}$ & $\begin{array}{l}16 \\
31\end{array}$ & $\begin{array}{l}0.055^{* *} \\
0.108\end{array}$ & $\begin{array}{l}8 \\
20\end{array}$ & $\begin{array}{l}0.023^{*} \\
0.069\end{array}$ & $\begin{array}{l}6 \\
7\end{array}$ & $\begin{array}{l}0.021 \\
0.028\end{array}$ & $\begin{array}{l}0 \\
0\end{array}$ & $\begin{array}{l}0.000 \\
0.000\end{array}$ \\
\hline (c) Never in compliance & $\begin{array}{l}1989-1992 \\
1993-1996\end{array}$ & $\begin{array}{l}2 \\
1\end{array}$ & $\begin{array}{l}0.091 \\
0.045\end{array}$ & $\begin{array}{l}1 \\
0\end{array}$ & $\begin{array}{l}0.045 \\
0.000\end{array}$ & $\begin{array}{l}0 \\
0\end{array}$ & $\begin{array}{l}0.000 \\
0.000\end{array}$ & $\begin{array}{l}0 \\
0\end{array}$ & $\begin{array}{l}0.000 \\
0.000\end{array}$ \\
\hline
\end{tabular}


Table III - - continued

Panel C: Top Executive Turnover by Quartiles of CERs

\begin{tabular}{|c|c|c|c|c|c|c|c|c|c|}
\hline All sample firms & $\begin{array}{l}1989-1992 \\
1993-1996\end{array}$ & $\begin{array}{l}63 \\
72\end{array}$ & $\begin{array}{l}0.137^{*} \\
0.157\end{array}$ & $\begin{array}{l}34 \\
42\end{array}$ & $\begin{array}{l}0.074 \\
0.091\end{array}$ & $\begin{array}{l}11 \\
12\end{array}$ & $\begin{array}{l}0.024 \\
0.026\end{array}$ & $\begin{array}{l}11 \\
12\end{array}$ & $\begin{array}{l}0.024 \\
0.026\end{array}$ \\
\hline (a) Always in compliance & $\begin{array}{l}1989-1992 \\
1993-1996\end{array}$ & $\begin{array}{l}23 \\
25\end{array}$ & $\begin{array}{l}0.153 \\
0.167\end{array}$ & $\begin{array}{l}10 \\
5\end{array}$ & $\begin{array}{l}0.067 \\
0.033\end{array}$ & $\begin{array}{l}1 \\
4\end{array}$ & $\begin{array}{l}0.007 \\
0.027\end{array}$ & $\begin{array}{l}1 \\
3\end{array}$ & $\begin{array}{l}0.007 \\
0.021\end{array}$ \\
\hline (b) Adopted compliance & $\begin{array}{l}y-4 \text { to } y-1 \\
y+1 \text { to } y+4\end{array}$ & $\begin{array}{l}38 \\
45\end{array}$ & $\begin{array}{l}0.132 \\
0.156\end{array}$ & $\begin{array}{l}23 \\
36\end{array}$ & $\begin{array}{l}0.080^{*} \\
0.125\end{array}$ & $\begin{array}{l}10 \\
8\end{array}$ & $\begin{array}{l}0.035 \\
0.028\end{array}$ & $\begin{array}{l}9 \\
9\end{array}$ & $\begin{array}{l}0.031 \\
0.031\end{array}$ \\
\hline (c) Never in compliance & $\begin{array}{l}1989-1992 \\
1993-1996\end{array}$ & $\begin{array}{l}2 \\
2\end{array}$ & $\begin{array}{l}0.091 \\
0.091\end{array}$ & $\begin{array}{l}1 \\
1\end{array}$ & $\begin{array}{l}0.045 \\
0.045\end{array}$ & $\begin{array}{l}0 \\
0\end{array}$ & $\begin{array}{l}0.000 \\
0.000\end{array}$ & $\begin{array}{l}1 \\
0\end{array}$ & $\begin{array}{l}0.045 \\
0.000\end{array}$ \\
\hline \multicolumn{10}{|c|}{ Panel D: Forced Top Executive Turnover by Quartiles of CERs } \\
\hline All sample firms & $\begin{array}{l}1989-1992 \\
1993-1996\end{array}$ & $\begin{array}{l}38 \\
50\end{array}$ & $\begin{array}{l}0.083^{*} \\
0.109\end{array}$ & $\begin{array}{l}17 \\
29\end{array}$ & $\begin{array}{l}0.037^{*} \\
0.063\end{array}$ & $\begin{array}{l}2 \\
0\end{array}$ & $\begin{array}{l}0.004 \\
0.000\end{array}$ & $\begin{array}{l}0 \\
0\end{array}$ & $\begin{array}{l}0.000 \\
0.000\end{array}$ \\
\hline (a) Always in compliance & $\begin{array}{r}1989-1992 \\
1993-1996\end{array}$ & $\begin{array}{l}18 \\
18\end{array}$ & $\begin{array}{l}0.120 \\
0.120\end{array}$ & $\begin{array}{l}6 \\
3\end{array}$ & $\begin{array}{l}0.040 \\
0.020\end{array}$ & $\begin{array}{l}0 \\
0\end{array}$ & $\begin{array}{l}0.000 \\
0.000\end{array}$ & $\begin{array}{l}0 \\
0\end{array}$ & $\begin{array}{l}0.000 \\
0.000\end{array}$ \\
\hline (b) Adopted compliance & $\begin{array}{l}y-4 \text { to } y-1 \\
y+1 \text { to } y+4\end{array}$ & $\begin{array}{l}18 \\
31\end{array}$ & $\begin{array}{l}0.063^{*} \\
0.108\end{array}$ & $\begin{array}{l}10 \\
26\end{array}$ & $\begin{array}{l}0.035^{*} \\
0.090\end{array}$ & $\begin{array}{l}2 \\
0\end{array}$ & $\begin{array}{l}0.007 \\
0.000\end{array}$ & $\begin{array}{l}0 \\
0\end{array}$ & $\begin{array}{l}0.000 \\
0.000\end{array}$ \\
\hline (c) Never in compliance & $\begin{array}{r}1989-1992 \\
1993-1996\end{array}$ & $\begin{array}{l}2 \\
1\end{array}$ & $\begin{array}{l}0.091 \\
0.045\end{array}$ & $\begin{array}{l}1 \\
0\end{array}$ & $\begin{array}{l}0.045 \\
0.000\end{array}$ & $\begin{array}{l}0 \\
0\end{array}$ & $\begin{array}{l}0.000 \\
0.000\end{array}$ & $\begin{array}{l}0 \\
0\end{array}$ & $\begin{array}{l}0.000 \\
0.000\end{array}$ \\
\hline
\end{tabular}

${ }^{-}$and ${ }^{\circ}$ denotes significance at the 0.01 and 0.05 levels respectively. 


\section{Table IV}

\section{Logit Regressions of Top Management Turnover on IAROA and Cadbury Report Compliance, 1989 through 1996}

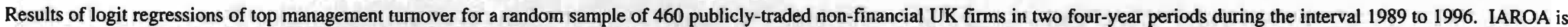

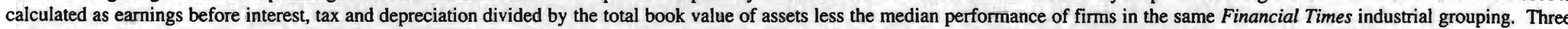

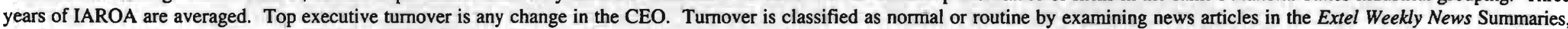

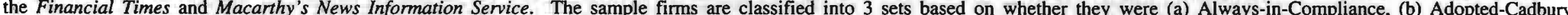

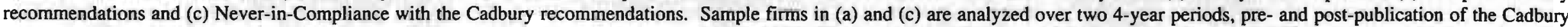

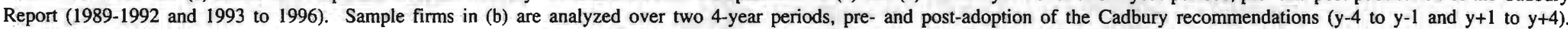

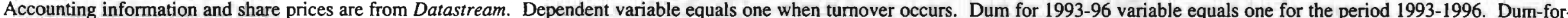

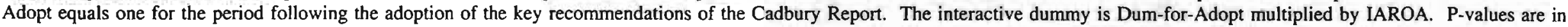
parentheses.

Panel A: Logit Regressions of All Top Executive Turnover on IAROA and Cadbury Compliance

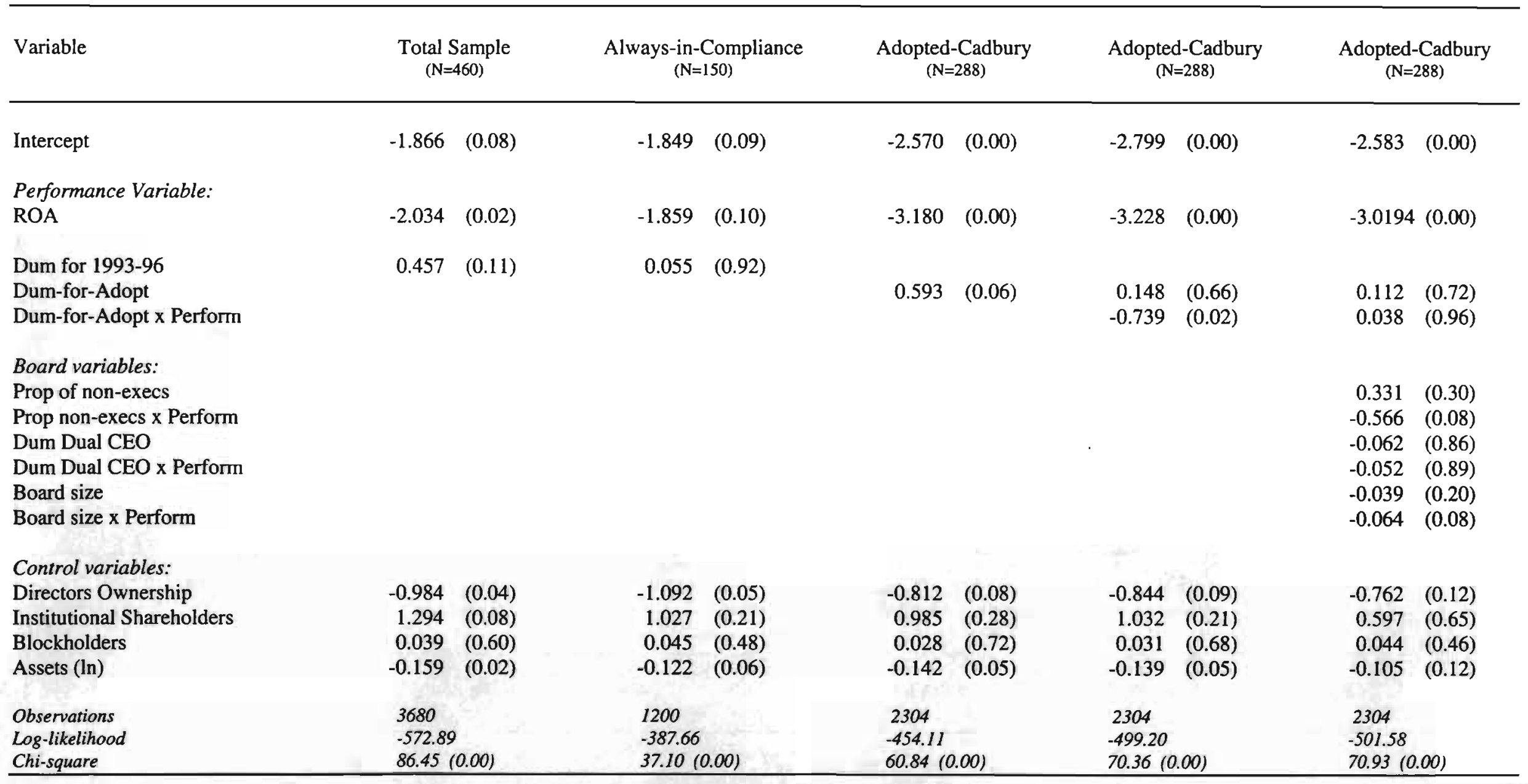


Table IV - - continued

Panel B: Logit Regressions of Forced Top Executive Turnover on IAROA and Cadbury Compliance

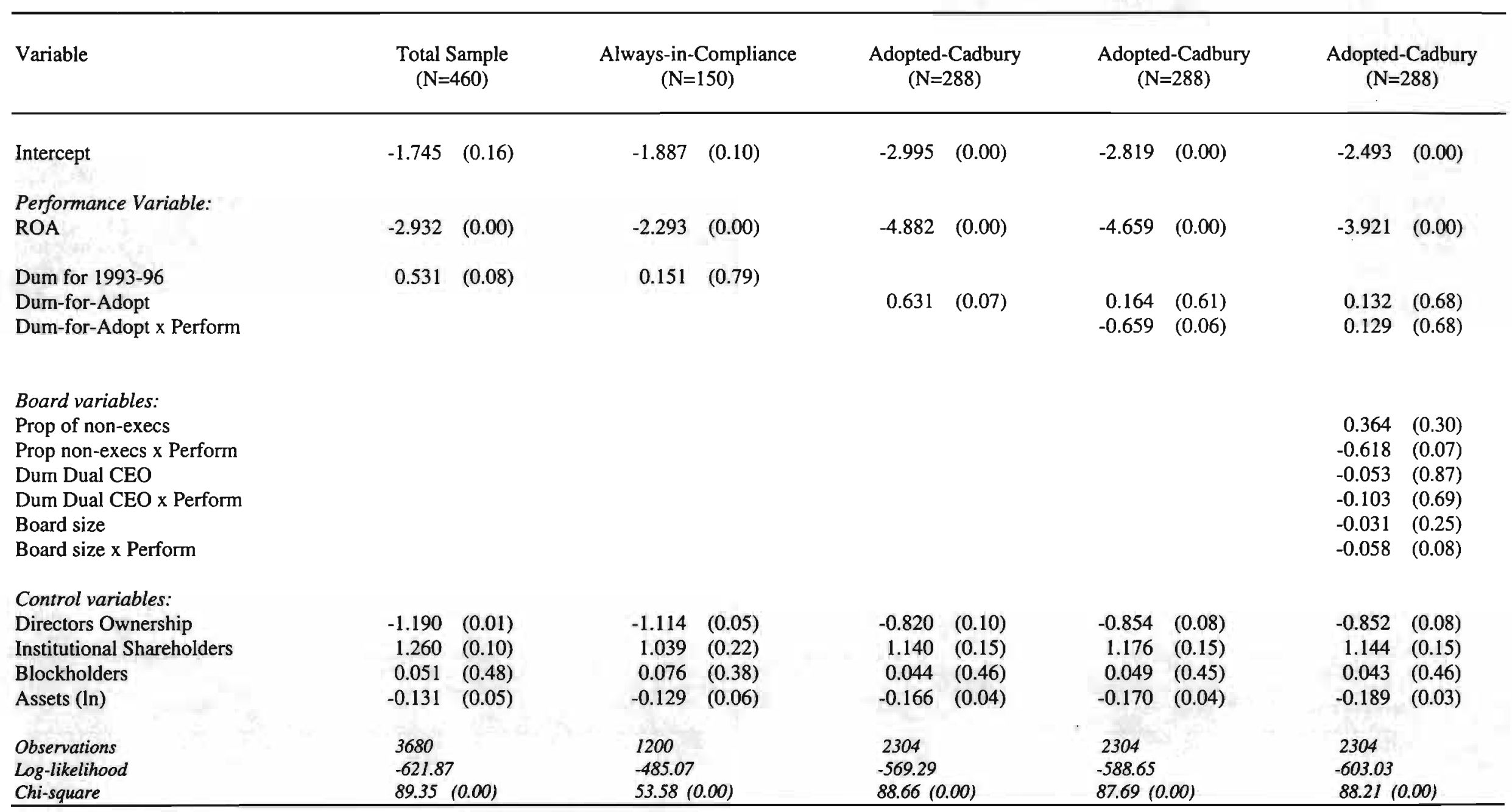




\section{Table V}

\section{Logit Regressions of Turnover on CER and Cadbury Report Compliance 1989 through 1996}

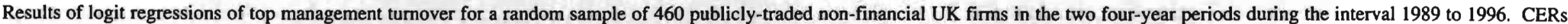

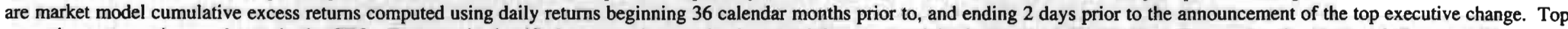

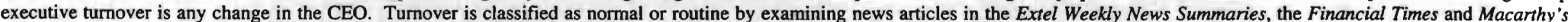

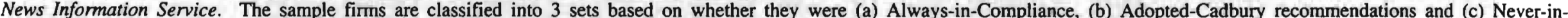

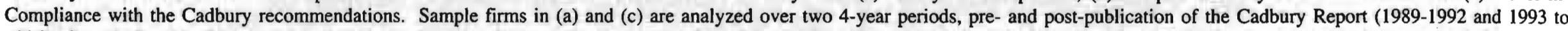

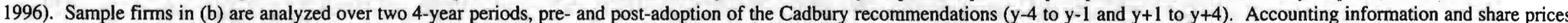

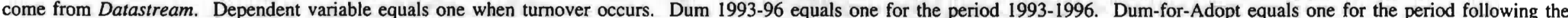
adoption of the key recommendations of the Cadbury Report. The interactive dummy is Dum-for-Adopt multiplied by CER. P-values are in parentheses.

Panel A: Logit Regressions of Top Executive Turnover on CER and Cadbury Compliance

\begin{tabular}{|c|c|c|c|c|c|c|}
\hline Variable & $\begin{array}{l}\text { Total Sample } \\
\qquad(\mathrm{N}=460)\end{array}$ & $\begin{array}{l}\text { Always-in-Compliance } \\
\qquad(\mathrm{N}=150)\end{array}$ & $\begin{array}{l}\text { Adopted-Cadbury } \\
\qquad(\mathrm{N}=288)\end{array}$ & $\begin{array}{l}\text { Adopted-Cadbury } \\
\qquad(\mathrm{N}=288)\end{array}$ & $\begin{array}{l}\text { Adopted } \\
\qquad(\mathrm{N}=\end{array}$ & $\begin{array}{l}\text { Cadbury } \\
\text { 288) }\end{array}$ \\
\hline Intercept & $-3.857 \quad(0.00)$ & $-2.629 \quad(0.00)$ & $-2.739 \quad(0.00)$ & $-2.695 \quad(0.00)$ & -2.458 & $(0.00)$ \\
\hline $\begin{array}{l}\text { Performance Variable: } \\
\text { Cumulative Excess Returns (CER) }\end{array}$ & $-0.021 \quad(0.00)$ & $-0.010 \quad(0.04)$ & $-0.025 \quad(0.00)$ & $-0.025 \quad(0.00)$ & -0.023 & $(0.00)$ \\
\hline $\begin{array}{l}\text { Dum for } 1993-96 \\
\text { Dum-for-Adopt } \\
\text { Dum-for-Adopt x Perform }\end{array}$ & $0.512 \quad(0.09)$ & $0.069 \quad(0.87)$ & $0.568 \quad(0.08)$ & $\begin{array}{rr}0.104 & (0.76) \\
-0.684 & (0.05)\end{array}$ & $\begin{array}{r}0.091 \\
-0.147\end{array}$ & $\begin{array}{l}(0.85) \\
(0.59)\end{array}$ \\
\hline $\begin{array}{l}\text { Board variables: } \\
\text { Prop of non-execs } \\
\text { Prop non-execs x Perform } \\
\text { Dum Dual CEO } \\
\text { Dum Dual CEO x Perform } \\
\text { Board size } \\
\text { Board size x Perform }\end{array}$ & & & & & $\begin{array}{r}0.257 \\
-0.559 \\
-0.062 \\
-0.058 \\
-0.037 \\
-0.052\end{array}$ & $\begin{array}{l}(0.44) \\
(0.09) \\
(0.83) \\
(0.85) \\
(0.37) \\
(0.09)\end{array}$ \\
\hline $\begin{array}{l}\text { Control variables: } \\
\text { Directors Ownership } \\
\text { Institutional Shareholders } \\
\text { Blockholders } \\
\text { Assets (ln) }\end{array}$ & $\begin{array}{rr}-0.932 & (0.04) \\
1.192 & (0.12) \\
0.059 & (0.39) \\
-0.088 & (0.15)\end{array}$ & $\begin{array}{rr}-1.194 & (0.02) \\
1.059 & (0.18) \\
0.071 & (0.29) \\
-0.128 & (0.04)\end{array}$ & $\begin{array}{rr}-0.810 & (0.08) \\
0.829 & (0.37) \\
0.039 & (0.51) \\
-0.076 & (0.17)\end{array}$ & $\begin{array}{rr}-0.814 & (0.08) \\
0.828 & (0.37) \\
0.031 & (0.68) \\
-0.085 & (0.16)\end{array}$ & $\begin{array}{r}-0.854 \\
0.939 \\
0.039 \\
-0.088\end{array}$ & $\begin{array}{l}(0.09) \\
(0.22) \\
(0.51) \\
(0.15)\end{array}$ \\
\hline $\begin{array}{l}\text { Observations } \\
\text { Log-likelihood } \\
\text { Chi-square }\end{array}$ & $\begin{array}{l}3680 \\
-595.25 \\
86.66(0.00)\end{array}$ & $\begin{array}{l}1200 \\
-494.65 \\
49.95(0.00)\end{array}$ & $\begin{array}{l}2304 \\
-521.84 \\
76.24(0.00)\end{array}$ & $\begin{array}{l}2304 \\
-584.28 \\
80.82(0.00)\end{array}$ & $\begin{array}{l}2304 \\
-613.82 \\
90.37\end{array}$ & $0.00)$ \\
\hline
\end{tabular}




\section{Table V - continued}

Panel B: Logit Regression of Forced Top Executive Turnover on CER and Cadbury Compliance

\begin{tabular}{|c|c|c|c|c|c|c|c|c|c|c|}
\hline \multirow{2}{*}{$\begin{array}{l}\text { Variable } \\
\text { Intercept }\end{array}$} & \multicolumn{2}{|c|}{$\begin{array}{l}\text { Total Sample } \\
\qquad(\mathrm{N}=460)\end{array}$} & \multicolumn{2}{|c|}{$\begin{array}{l}\text { Always-in-Compliance } \\
\qquad(N=150)\end{array}$} & \multicolumn{2}{|c|}{$\begin{array}{l}\text { Adopted-Cadbury } \\
\qquad(\mathrm{N}=288)\end{array}$} & \multicolumn{2}{|c|}{$\begin{array}{l}\text { Adopted-Cadbury } \\
\qquad(\mathrm{N}=288)\end{array}$} & \multicolumn{2}{|c|}{$\begin{array}{l}\text { Adopted-Cadbury } \\
\qquad(\mathrm{N}=288)\end{array}$} \\
\hline & -4.184 & $(0.00)$ & -2.938 & $(0.00)$ & -5.029 & $(0.00)$ & -5.012 & $(0.00)$ & -4.667 & $(0.00)$ \\
\hline \multicolumn{11}{|l|}{ Performance Variable: } \\
\hline Cumulative Excess Returns (CER) & -0.038 & $(0.00)$ & -0.017 & $(0.02)$ & -0.057 & $(0.00)$ & -0.061 & $(0.00)$ & -0.052 & $(0.00)$ \\
\hline Dum for $1993-96$ & 0.592 & $(0.04)$ & 0.052 & $(0.84)$ & & & & & & \\
\hline Dum-for-Adopt & & & & & 0.527 & $(0.09)$ & 0.217 & $(0.63)$ & 0.031 & $(0.92)$ \\
\hline Dum-for-Adopt x Perform & & & & & & & -0.574 & $(0.08)$ & -0.129 & $(0.68)$ \\
\hline \multicolumn{11}{|l|}{ Board variables: } \\
\hline Prop of non-execs & & & & & & & & & 0.273 & $(0.39)$ \\
\hline Prop non-execs x Perform & & & & & & & & & -0.557 & $(0.09)$ \\
\hline Dum Dual CEO & & & & & & & & & -0.061 & $(0.83)$ \\
\hline Dum Dual CEO x Perform & & & & & & & & & -0.041 & $(0.92)$ \\
\hline Board size & & & & & & & & & -0.039 & $(0.35)$ \\
\hline Board size $x$ Perform & & & & & & & & & -0.046 & $(0.10)$ \\
\hline \multicolumn{11}{|l|}{ Control variables: } \\
\hline Directors Ownership & -0.949 & $(0.04)$ & -0.955 & $(0.05)$ & -0.829 & $(0.08)$ & -0.844 & $(0.07)$ & -0.771 & $(0.12)$ \\
\hline Institutional Shareholders & 1.057 & $(0.20)$ & 1.106 & $(0.19)$ & 0.621 & $(0.60)$ & 0.625 & $(0.60)$ & 0.560 & $(0.68)$ \\
\hline Blockholders & 0.079 & $(0.25)$ & 0.103 & $(0.07)$ & 0.045 & $(0.48)$ & 0.044 & $(0.47)$ & 0.044 & $(0.47)$ \\
\hline Assets (ln) & -0.108 & $(0.08)$ & -0.140 & $(0.03)$ & -0.041 & $(0.34)$ & -0.049 & $(0.32)$ & -0.041 & $(0.34)$ \\
\hline Observations & 3680 & & 1200 & & 2304 & & 2304 & & 2304 & \\
\hline Log-likelihood & -634.59 & & -548.51 & & -602.44 & & -589.02 & & -618.29 & \\
\hline Chi-square & 119.72 & $(0.00)$ & 48.291 & $.00)$ & 55.25 & $.00)$ & 55.66 & $.00)$ & 78.29 & $0.00)$ \\
\hline
\end{tabular}


No. 93-101 Gordon M. Phillips, and Robert J. Weiner

"Information and Normal Backwardation as Determinants of Trading Performance: Evidence from the North-Sea Oil Forward Market." 1994. The Economic Journal.

No. 93-102 Stephen R. Goldberg and Frank L. Heflin

"The Association Between the Level of International Diversification and Risk."

No. 93-103 John A. Carlson

"Risk Aversion, Foreign Exchange Speculation and Gambler's Ruin."

No. 93-104 John A. Carlson, Aasim M. Husain, and Jeffrey A. Zimmerman

"Penalties and Exclusion in the Rescheduling and Forgiveness of International Loans."

No. 93-105 Kent D. Miller

"Industry and Country Effects on Manager's Perceptions of Environmental Uncertainties."

1993. Journal of International Business Studies, 24: 693-714.

No. 93-106 Stephen R. Goldberg and Joseph H. Godwin

"Foreign Currency Translation Under Two Cases-Integrated and Isolated Economies."

No. 93-107 Kent D. Miller

"A Comparison of Managers' Uncertainty Perceptions and Country Risk Indices."

No. 93-108 Jon D. Haveman

"The Effect of Trade Induced Displacement on Unemployment and Wages."

No. 93-109 Jon D. Haveman

"Some Welfare Effects of Dynamic Customs Union Formation."

No. 93-110 John A. Carlson and Insook Kim

"Central Banks' Expected Profits From Intervention."

No. 94-001 Casper G. De Vries, Phillip A. Stork, and Kees G. Koedijk

"Between Realignments and Intervention: The Belgian Franc in the European Monetary System."

No. 94-002 Casper G. de Vries and K. U. Leuven

"Stylized Facts of Nominal Exchange Rate Returns."

No. 94-003 Kent D. Miller

"Operational Flexibility Responses to Environmental Uncertainties."

No. 94-004

Kent D. Miller

"Economic Exposure and Integrated Risk Management."

No. 94-005

Kent D. Miller

"Diversification Responses to Environmental Uncertainties."

No. 94-006 John M. Hannon, Ing-Chung Huang, and Bih-Shiaw Jaw

"International Human Resource Strategy and Its Determinants: The Case of Multinationals and Their Subsidiaries in Taiwan." 
No. 94-007

No. 94-008

No. 94-009

No. 94-010

No. 94-011

No. 94-012

No. 94-013

No. 94-014

No. 94-015

No. 94-016

No. 94-017

No. 94-018

No. 94-019

No. 94-020

No. 94-021

No. $94-022$

No. 95-001

No. 95-002
John M. Hannon, Ing-Chung Huang, and Bih-Shiaw Jaw

"International Human Resource Strategy and Control: The Case of Multinationals and Their Subsidiaries."

John M. Hannon and Yoko Sano

"Customer-Driven Human Resource Policies and Practices in Japan."

John A. Carlson and Insook Kim

"Leaning Against the Wind: Do Central Banks Necessarily Lose?"

John A. Carlson and David W. Schodt

"Beyond the Lecture: Case Teaching and the Learning of Economic Theory."

Alok R. Chaturvedi, Hemant K. Jain, and Derek L. Nazareth

"Key Information Systems Management Issues in Developing Countries: Differences in the Indian and US Contexts."

Jon Haveman,

"The Influence of Changing Trade Patterns on Displacements of Labor."

Stephen Goldberg, Charles A. Tritschler, and Joseph H. Godwin

"Financial Reporting for Foreign Exchange Derivatives."

Charles Noussair, Charles Plott, and Raymond Riezman

"Una investigacion experimental sobre la estructura del comercia interncional (Spanish Version)."

Translated: "An Experimental Investigation About the Structure of International Commerce."

Marie Thursby and Richard Jensen

"Patent Races, Product Standards, and International Competition."

Kent D. Miller and Jeffrey J. Reuer

"Firm Strategy and Economic Exposure to Foreign Exchange Rate Movements."

John Hannon and Yoko Sano

"The Determinants of Corporate Attractiveness in Japan."

John Hannon, Ing-Chung Huang, and Cheng-Chen Lin

"The Mediating Effect of Pre/Post Assignment Acitivities on the Quality of Work Life of Expatriates:

Evidence for Managers in the P.R.C."

John Hannon, Ing-Chung Huang, and Cheng-Chen Lin

"The Mediating Effects of Organization Commitment and Job Involvement on the Relationship Between Quality of Work Life and Customer Service Attitudes."

John A. Carlson and Marc Surchat

"A Model for Filter-Rule Gains in Foreign Exchange Markets."

Ch.N. Noussair, Ch.R. Plott, and R. Riezman

"The Principles of Exchange Rate Determination in an International Finance Experiment."

Stephen R. Goldberg, Joseph H. Godwin, Myung-Sun Kim, and Charles A. Tritschler "On The Determinants of Corporate Hedging With Financial Derivatives."

Timothy B. Folta

"Sovereignty Conditions and Governance Modes: An Option Theory Approach."

John A. Carlson and Dong-Geun Han

"Monetary Coordination, Fixed Exchange Rates and Noisy Markets." 
No. 95-003

No. 95-004

No. 95-005

No. 95-006

No. 95-007

No. 96-001

No. 96-002

No. $96-003$

No. 96-004

No. 96-005

No. 96-006

No. 96-007

No. 96-008

No. 96-009

No. 96-010

No. 96-011

No. 96-012

No. 96-013
Jon D. Haveman

"Can Barriers to Trade Make a Differential?"

Kent D. Miller and Jeffrey J. Reuer

"Asymmetric Corporate Exposures to Foreign Exchange Rates."

Gerald J. Lynch and Bradley T. Ewing

"Money Growth Variability and the Term Structure of Interest Rates in Japan."

Nicholas C. Petruzzi and Maqbool Dada

"Inventory and Pricing in Global Operations: Learning from Observed Demand."

Kala Krishna and Marie Thursby

"Whither Flat Panel Displays?"

Thomas Brush, Catherine Maritan, and Aneel Karnani

"Managing a Network of Plants Within Multinational Firms."

John J. McConnell, Heidi J. Dybevik, David Haushalter, and Erik Lie

"A Survey on Domestic and International Stock Exchange Listings with Implications for Markets and Managers."

Kala Krishna, Suddhasatwa Roy, and Marie Thursby

"Implementing Market Access."

Jon Haveman, David Hammels

"Trade Creation and Trade Diversion: New Empirical Results."

Riki Takeuchi, John M. Hannon

"Antecedents of Expatriate Spouse Adjustments: An Analysis of Japanese Spouses in the United States."

Bih-Shiaw Jaw, John M. Hannon

"Determinants of International and Intercultural Human Resource Control: The Case Of Taiwanese Subsidiaries in the People's Republic of China."

John M. Hannon, Riki Takeuchi

"Adjustment and Job Satisfaction as Antecedents of Intent to Stay: The Case of Japanese Expatriates in the United States."

John M. Hannon

"Using International Human Resource Management to Inform the Business Intelligence Function."

Jeffrey J. Reuer, Kent D. Miller

"Agency Costs and the Performance Implications of International Joint Venture Internalization."

Neven Valev

"International Lending by U.S. Banks."

Kala Krishna, Marie Thursby, and Suddhasatwa Roy

"Implementing Market Access." (revised)

Jon D. Haveman

"The Effect of Trade Induced Displacement on Unemployment and Wages."

Robert A. Buckle and John A. Carlson

"Inflation and Asymmetric Price Adjustment." 
No. 97-001

No. 97-002

No. 97-003

No. 97-004

No. 97-005

No. 97-006

No. 97-007

No. 97-008

No. 97-009

No. 98-001

No. 98-002

No. 98-003

No. 98-004

No. 98-005

No. 98-006

No. 98-007

No. 98-008

No. 99-001
Jeffrey J. Reuer

"Shareholder Wealth Effects of Joint Venture Termination: A Transaction Cost Analysis."

Jon Haveman and David Hummels

"What Can We Learn from Bilateral Trade? Gravity and Beyond."

Douglas Bowman, John U. Farley, and David C. Schmittlein

"Cross-National Empirical Generalization of a Supplier Selection and Usage Model for Foreign Exchange Services."

Kent D. Miller

"Measurement of Perceived Environmental Uncertainties: Response and Extension."

John A. Carlson, C. O. Osler

"Rational Speculators and Exchange Rate Volatility."

Marie Thursby, Kala Krishna, and Suddhasatwa Roy

"Procompetitive Market Access," Forthcoming, Business and Economics for the $21^{\text {st }}$ Century Vol. 1.

John A. Carlson

"Currency Boards, Expectations and Inflation Persistence."

Jon Haveman, Usha C. Nair, and Jerry G. Thursby

"The Effects of Protection on the Pattern of Trade: A Disaggregated Analysis," Forthcoming, Business and Economics for the $21^{\text {st }}$ Century, Vol. 1.

George Horwich

"Economic Lessons of the Kobe Earthquake."

John J. McConnell, Kenneth A. Carow, and Gayle R. Erwin

"Financing Publicly Traded U.S. Corporations in Public and Private Security Markets, 1970-1997:

Where, How, How Much, With What, When, and Why."

Timothy N. Cason, Tatsuyoshi Saijo, and Takehiko Yamato

"Voluntary Participation and Spite in Public Good Provision Experiments: An International

Comparison."

Jon D. Haveman, Janet S. Netz, and Vivian Lei

"International Integration and Growth: A Survey and Empirical Investigation."

Keith V. Smith, Nabil T. Khoury, and Peter I. MacKay

"Comparing Working Capital Practices in Canada, the United States, and Australia: A Note."

John A. Carlson and Neven T. Valev

"Expectations Formation and Inflation Persistence."

John A. Carlson and Carol L. Osler

"Determinants of Currency Risk Premiums."

Jon D. Haveman, Usha Nair-Reichert, and Jerry Thursby

"Trade Reduction, Diversion and Compression: Empirical Regularities in the Effect of Protective Measures."

Kale Krishna, Suddhasatwa Roy, and Marie Thursby

"Can Subsidies for MARs be Procompetitive?"

Gabriele Camera and Johannes Winkler

"Stores, Prices and Currency Substitution" 
No. 99-003 Timothy N. Cason, Tatsuyoshi Saijo and Takehiko Yamato

"Voluntary Participation and Spite in Public Good Provision Experiments: An International Comparison"

No. 99-004 Jay Dahya, John J. McConnell and Nickolaos G. Travlos

"The Cadbury Committee, Corporate Performance and Top Management Turnover"

No. 99-005 David J. Denis, Diane K. Denis and Keven Yost

"Global Diversification, Industrial Diversification and Firm Value"

No. 99-006 Timothy B. Folta and Walter J. Ferrier

"The Effect of National Culture on Partner Buyouts in Cross-Border Biotechnology Alliances"

No. 99-007 Jon D. Haveman and Jerry G. Thursby

"The Impact of Tariff and Non-Tariff Barriers to Trade in Agricultural Commodities:

A Disaggregated Approach"

No. 99-008 Huseyin Gulen and Stewart Mayhew

"Stock Index Futures Trading and Volatility in International Equity Markets"

No. 99-009 Stefan Lutz and Alessandro Turrini

"Skills, Labour Costs and Vertically Differentiated Industries: A General Equilibrium Analysis"

No. 99-010 Michael Watts and Alexander Kovzik

"Reforming Undergraduate Economics Instruction in the Former Soviet Union" 